\title{
Angola: First Review Under the Stand-By Arrangement and Request for a Modification of a Performance Criterion
}

The following documents have been released and are included in this package:

- $\quad$ The staff report, prepared by a staff team of the IMF, following discussions that ended on March 12, 2010, with the officials of Angola on economic developments and policies. Based on information available at the time of these discussions, the staff report was completed on April 26, 2010. The views expressed in the staff report are those of the staff team and do not necessarily reflect the views of the Executive Board of the IMF.

- A staff statement

- A press release

- $\quad$ A statement by the Executive Director for Angola.

The document(s) listed below will be separately released.

Extended Letter of Intent sent to the IMF by the authorities of Angola* Technical Memorandum of Understanding*

*Also included in staff report

The policy of publication of staff reports and other documents allows for the deletion of market-sensitive information.

Copies of this report are available to the public from

International Monetary Fund • Publication Services $70019^{\text {th }}$ Street, N.W. • Washington, D.C. 20431

Telephone: (202) 623-7430 • Telefax: (202) 623-7201

E-mail: publications@imf.org Internet: http://www.imf.org

\section{International Monetary Fund Washington, D.C.}




\title{
INTERNATIONAL MONETARY FUND
}

\section{ANGOLA \\ First Review under the Stand-By Arrangement and Request for a Modification of a Performance Criterion ${ }^{1}$}

\author{
Prepared by the African Department \\ (In consultation with other departments)
}

Approved by Sean Nolan and Dhaneshwar Ghura

April 26, 2010

\section{Context:}

\section{Executive Summary}

- The Executive Board approved a 27-month Stand-By Arrangement in the amount of SDR 858.9 million (300 percent of quota) on November 23, 2009 (Country Report No. 09/320), and the first purchase of SDR 229 million was made immediately thereafter. Discussions for the first review were held in March: the program appears to be broadly on track, with all but two endDecember 2009 performance criteria being met. Staff recommends completion of the first SBA review and supports the waivers requested, which relate to the end-March test date.

- The authorities' reforms are beginning to bear fruit in terms of achieving key program goals, and the heavy foreign exchange market pressures that were evident at the program negotiations stage (September 2009) have eased. The reintroduction of the foreign exchange auction system has led to a significant and orderly adjustment in the official rate, and together with a modest appreciation of the parallel rate, has narrowed the spread between the two markets. Expenditure restraint delivered encouraging results in terms of a tight fiscal stance, although the government has continued to accumulate domestic arrears, reflecting ongoing difficulties in raising funds domestically.

\section{Key Pillars of the First SBA Review:}

Staff and the authorities agreed that further actions are needed to reduce remaining vulnerabilities and ensure a smooth return of the economy to a sustainable path. In particular, it was agreed that the authorities need to:

- Allow a more competitive bidding in the auction to facilitate full price discovery in the foreign exchange auctions and yield a more market-determined exchange rate. A series of measures to enhance liquidity management and keep monetary policy tight are being implemented by the BNA to support the goal of further normalizing conditions in the foreign exchange market.

- $\quad$ Strengthen debt management capacity while allowing an increase in Angola's program external debt limit to finance basic infrastructure projects in line with the authorities' rehabilitation program.

- $\quad$ Reduce fiscal risks by steadfastly implementing the expenditure restraining measures in the 2010 budget and enhancing public financial management.

\footnotetext{
1 A staff team comprising Messrs. Leigh (head), Klein, Xiao (all AFR), and Veyrune (MCM) visited Luanda during March 2-12, 2010. Ms. Grochalska (FIN), Ms. SenGupta (LEG) and Mr. Gemayel (SPR) joined the mission during March 3-10 to assist with technical issues. Mr. Papaioannou (MCM) joined the mission during March 7-11 to discuss lessons for Angola from international experience in sovereign asset-liability management. Mr. Nolan (AFR) also joined for part of the mission. The team held discussions with the Coordinating Minister for Economic Policies, the Minister of Finance, the Minister of Planning, the Governor of the Central Bank, other senior government officials, commercial bankers, the private sector and donors.
} 
I. Recent Developments and Outlook …...................................................................... 3

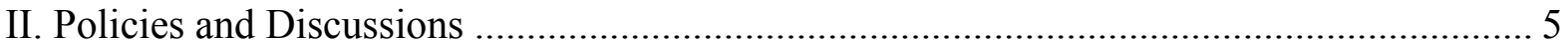

A. Monetary and Exchange Rate Policies.......................................................... 5

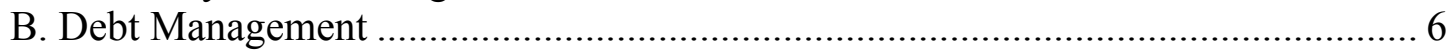

C. Fiscal Policy and Public Financial Management............................................... 10

III. Program Monitoring, Safeguard and Other Issues ................................................. 12

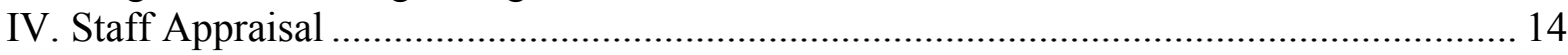

Tables

1. Selected Economic and Financial Indicators, 2007-15 ........................................... 23

2a. Summary of Government Operation, 2006-11 ...................................................... 24

2b. Summary of Government Operations, 2006-11 .................................................... 25

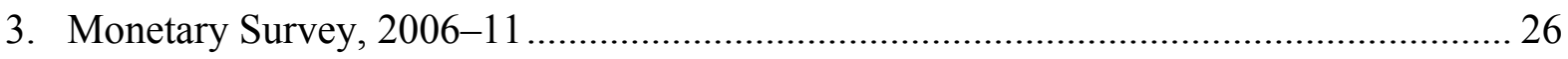

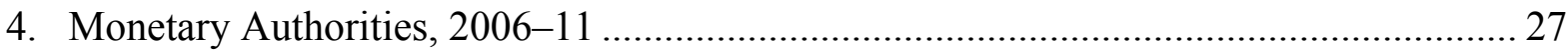

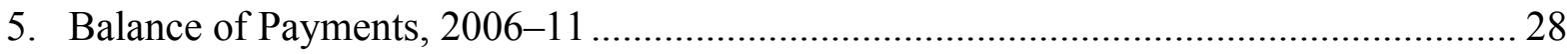

6. Banking System Financial Soundness Indicators, 2003-09 ...................................... 29

7. External Financing Requirements and Sources, 2009-11 .......................................... 30

8. Indicators of Capacity to Repay the Fund, 2009-16.................................................. 31

9. Angola Reviews and Disbursements under the Proposed 27-Month Stand-By-

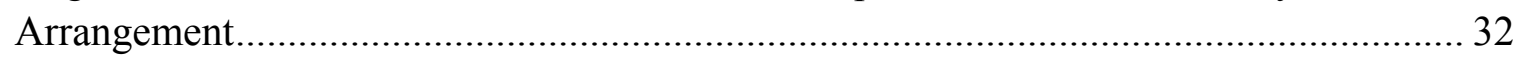

10. External Debt Sustainability Framework, 2004-2015 f............................................ 33

11. Public Sector Debt Sustainability Framework, 2004-15 ........................................ 34

Figures

1. Angola in a Cross-Country Perspective, Based on Selected Group of Oil Exporting

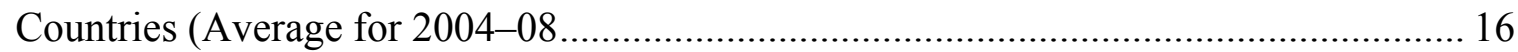

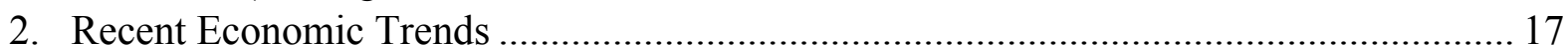

3. External Debt Sustainability: Bound Test, Percent of GDP ........................................ 21

4. Public Debt Sustainability: Bound Tests .................................................................. 22

Box

1. Strengthening Debt Management in Angola ......................................................... 11

Appendix

I. Extended Letter of Intent ......................................................................................... 36

Attachment

I. Technical Memorandum of Understanding ................................................................. 45

Annexes

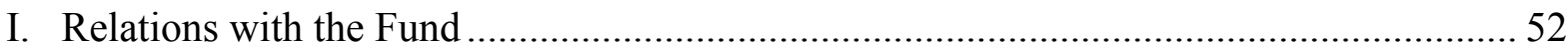

II. World Bank-IMF Joint Management Plan .............................................................. 55

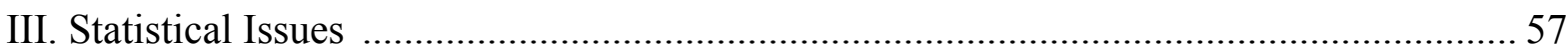




\section{RECENT DEVELOPMENTS AND OUTLOOK}

1. Context. Economic developments have been broadly in line with program expectations. The increased global demand for oil has revitalized Angola's oil sector, bringing in higher oil revenues. This, together with government's spending restraint and a more moderate pace of capital outflows, also strengthened the external position, allowing for some accumulation of international reserves (Text Figure 1). Economic growth accelerated in the second half of 2009 , in line with staff projections, as both the oil and non-oil sectors expanded. Although the official exchange rate depreciated by 15 percent in the Text figure 1. Angola: Usable Net International Reserves and the Oil Export Receipts fourth quarter of the year, CPI

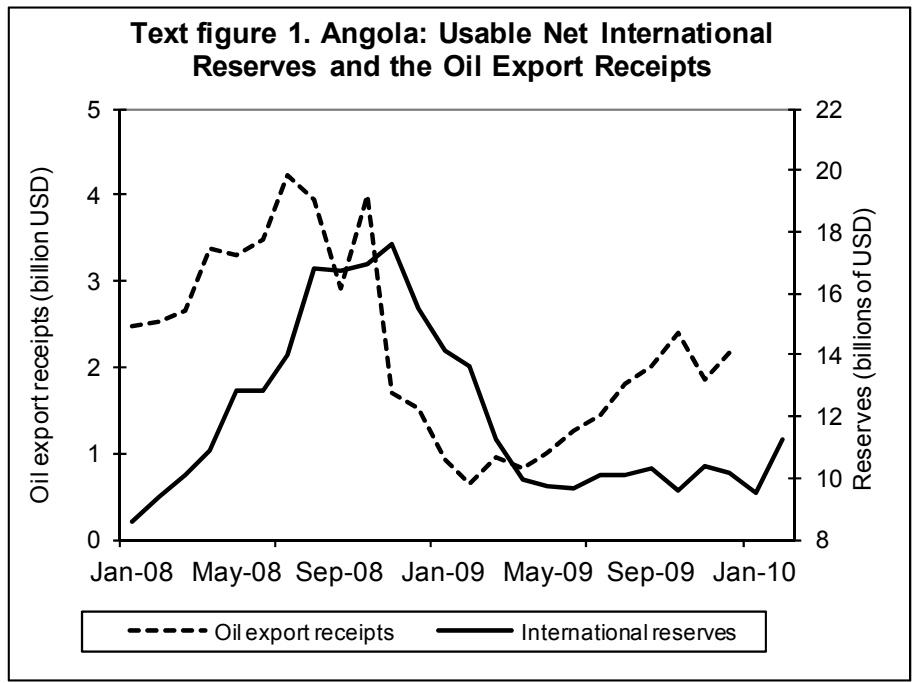
inflation increased only slightly in 2009, partly reflecting improved market confidence, which facilitated a modest appreciation of the parallel market rate.

2. Politics. The National Assembly in January 2010 approved a new constitution that establishes a presidential-parliamentary system in which the president is to be elected by parliament rather than by a direct popular vote. Consequently, the presidential elections, initially scheduled for 2009, have now been dropped.

3. Monetary and exchange rate. The resumption of the foreign exchange auctions has facilitated a normal channeling of foreign currency in the primary market and an orderly exchange rate adjustment. The

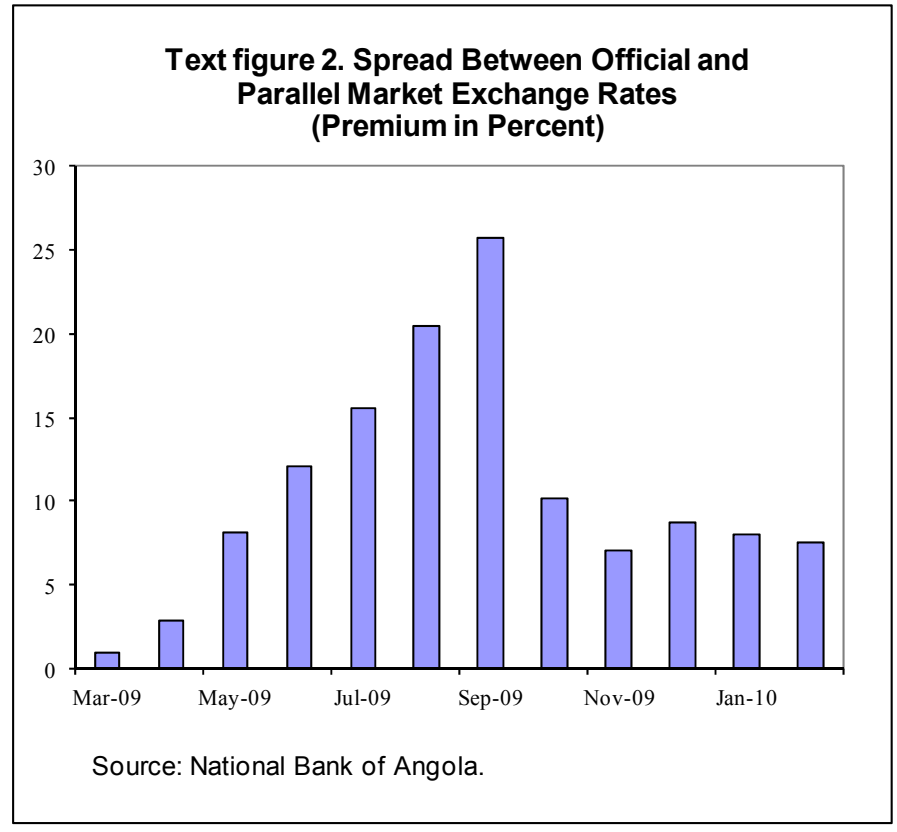
depreciation also helped in narrowing the spread with the parallel market rate (Figure 2). Nevertheless, banks' demand for foreign currency remains above the level offered by the National Bank of Angola (BNA), pointing to problems with the workings of the auction system. The effectiveness of monetary policy has been undermined by the Treasury's reluctance to accept higher interest 
rates on its bond sales, along with weak liquidity management by the BNA, which is competing with Treasury bills sales at the very short end of the yield curve.

4. Fiscal policy. Fiscal data for the second half of 2009 suggests that budget execution was tight and supportive of the program's objective of stabilizing reserves, though oil revenues were lower than anticipated in the program due to lower production. Expenditure restraint guided by the 2009 supplementary budget delivered encouraging results in terms of a tight fiscal stance, although the government continued to accumulate domestic arrears, reflecting ineffective domestic financing operations. In mid-December, the National Assembly adopted the 2010 budget, which is consistent with program goals.

5. Program performance. All but two end-December 2009 performance criteria were met; the two targets that were missed relate to the central government's accumulation of external arrears (negligible) and domestic arrears (about 1 $1 \frac{1}{2}$ percent of GDP in the fourth quarter) (see extended Letter of Intent, $\mathbb{T} 13$ ). The indicative target for the non-oil primary fiscal balance was met with a wide margin thanks to higher than expected non-oil revenues, although social spending was slightly below target, due to weaknesses in the social delivery system. The banking system, which has large capital buffers, has been relatively resilient to the exchange rate shock. The BNA has finalized regulations on amending the provisioning requirements to manage the credit risk of foreign currency loans and developing off-site supervisory tools (March 2010 structural benchmarks).

6. Outlook. While the recent signs of recovery in the global economy are likely to support economic activity in Angola, mainly through the oil sector, risks continue to be tilted to the downside given the uncertain external outlook:

- Growth and inflation: The outlook for an economic rebound in Angola in 2010 has generally not changed since the program was approved. It appears that the non-oil sector is recovering at a healthy pace while the oil sector is expanding thanks to improved external conditions. Inflation is expected to decline further in 2010, reflecting fiscal tightening and a better external position (and exchange rate outlook).

- $\quad$ Fiscal and external positions: The fiscal and external current accounts are now expected to record surpluses in 2010 and 2011 that will be slightly higher than projected, thanks to higher than envisaged oil prices (Table 1). That said, this will not translate fully into higher international reserves, given that a planned sovereign bond issue is likely to be significantly scaled down, and that as oil prices rise, outward foreign direct investment increases significantly as companies receive higher costrecovery payments.

Staff and the authorities agreed that, with the exception of the external borrowing ceiling, it was premature to revise the program targets, including for reserve accumulation, given both the data delay and the difficulties of distinguishing 
between transitory and permanent developments. This issue will be reviewed during the second SBA review.

\section{Policies AND Discussions}

7. While the program is broadly on track, the return of the economy to a sustainable path is not without challenges. Policy discussions focused on measures to improve the workings of the foreign exchange market and monetary policy, to enhance debt management, to steadfastly execute spending in the 2010 budget, and to further improve public financial management. These issues are discussed below.

\section{A. Monetary and Exchange Rate Policies}

8. While the renewal of the auction system has generated a significant exchange rate adjustment, managing liquidity has proved difficult and the foreign exchange market has yet to produce a truly market clearing price.

- $\quad$ The program specifies that tight monetary policy is crucial in supporting the normalization of the foreign exchange markets and the BNA needs to use BNA notes to absorb excess liquidity. However, liquidity management has been weak, as manifested in the continuous presence of excess demand in the foreign exchange markets and the still high pace of money growth. The BNA's notes face competition from treasury securities at the same maturities, with the latter benefiting from taxation advantages and from their eligibility as assets to meet up to 30 percent of the reserve requirement. Consequently, the BNA has limited instruments to absorb banks' excess liquidity, which, if channeled to speculative demand for foreign currency, places pressure on the exchange market. Moreover, the practice of allowing banks to maintain their reserve requirements in foreign exchange has given them ample room for speculation (with the share of U.S. dollars in required reserves increasing over time).

- $\quad$ Staff's analysis of the auction results suggests that there are still barriers to a market determined exchange rate, causing recurrent excess demand for foreign currency. The authorities' fear of floating is translating into low tolerance for further exchange rate adjustment, with high bids in the auction rejected without applying a well-defined and transparent "outliers" policy. Staff noted that communication between the BNA and market participants on the timing of the auctions is irregular, creating further uncertainty and hampering the functioning of the primary foreign currency market.

9. Thus, the authorities and staff agreed that steps need to be taken to improve liquidity management and bring about a fully market determined exchange rate.

- The mission and the BNA agreed on measures to improve liquidity management, including a) the removal of government securities from the class of assets eligible for 
meeting reserve requirements, b) some reduction of the reserve requirement ratio (currently at 30 percent) to soften the impact of this move on the banks, c) the discontinuation of the practice of accepting foreign currency for reserve requirement purposes (foreign currency deposits presently used to meet the reserve requirement can be reduced but not increased), and d) a phased reduction of the net open position limits on banks. As a supporting measure, and to ease any adverse impact on budget financing, the authorities intend to issue competitively priced government paper at longer maturities.

- $\quad$ These moves will be followed by elimination of the remaining administrative controls that affect the foreign exchange auction, with intervention (consistent with the program's net international reserves floor) being used to limit excessive volatility in the exchange rate. The BNA is also committed to streamlining the bidding process in order to make it more transparent while allowing greater flexibility in the exchange rate to better reflect market forces. This includes issuing to market makers a new auction circular that will clarify the parameters of the auction system and limit discretionary selection of bids. Efforts are also being made to strengthen communication with the banks through, for instance, setting a fixed time for auctions to reduce uncertainty and allow market participants to prepare. Additionally, the BNA has committed to reviewing the administrative requirements imposed on banks with a view to unifying the secondary and parallel markets. ${ }^{2}$

\section{B. Debt Management}

10. The authorities see a pressing need to invest heavily in projects to improve the country's physical infrastructure, severely damaged in the 30-year civil war, as a means to eliminate supply bottlenecks and accelerate economic development. ${ }^{3}$

Financing for these projects is available under investment framework agreements with several countries (most importantly China and Brazil), and, with a relatively low external debt ratio, the proposed borrowing levels do not pose a significant threat to debt vulnerability. They noted that, given Angola's middle income status and its abundant oil reserves, access to concessional financing is very limited, hence the need to make use of nonconcessional funding.

\footnotetext{
${ }^{2}$ These requirements include the " 4 percent rule," which is the maximum allowed spread above the official rate for transactions by banks with customers.

${ }^{3}$ There was a ceiling of $\$ 2$ billion on nonconcessional borrowing, plus an assumed $\$ 0.75$ billion in concessional borrowing. The assumed concessional borrowing is now considered unlikely to materialize.
} 


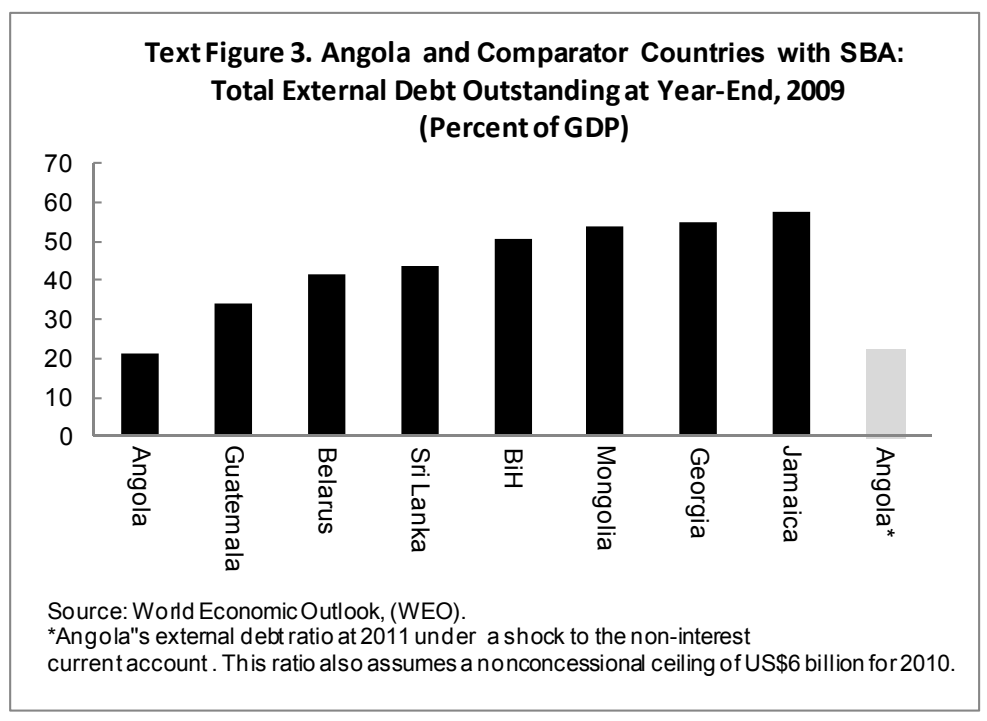

11. Following extensive discussions, staff and the authorities agreed to an increase of the ceiling on the contracting of new external borrowing to \$6 billion-a level that staff deemed acceptable, conditional on program commitments to ensure that the new borrowing is well managed and debt management capacity is strengthened. ${ }^{4}$

- $\quad$ The government's high external debt contracting need for 2010 does not involve higher-than-budgeted investment (and hence does not alter the macroeconomic framework), but instead is a correction of the composition of the programmed external borrowing to reflect lower disbursements from existing debt contracts, and correspondingly higher borrowings under new contracts. The bunching of new contracts in 2010 reflects: the effects of a freeze on contracting of new debt for much of 2009, the need to finalize project financing before existing framework agreements expire, and improvements in the government's execution rate for capital spending. ${ }^{5}$

- Despite significant new borrowings in 2010, the programmed net external borrowing for the year is some $\$ 1.3$ billion (1.5 percent of GDP), with the debt-GDP ratio expected to rise by only 1 percent from 2009 to 2010 . The authorities confirmed that

\footnotetext{
${ }^{4}$ Given Angola's recent graduation to middle income country status, the performance criterion will be based on total external borrowing rather than nonconcessional borrowing as in the original program.

${ }^{5}$ The authorities attributed recent constraints on expanding investment outlays to the cumbersome procedures under the existing procurement system. They are working to (i) strengthen public expenditure tracking, (ii) improve public procurement, (iii) train personnel to perform administrative tasks that would ensure effective utilization of the procurement system, and (iv) improve identification, costing and planning of projects.
} 
the planned bond issuance (intended to boost reserves) would be in compliance with the revised debt ceiling, even if it means postponing some projects to 2011 . $^{6}$

- $\quad$ Viewed from a medium-term perspective, the contracting of external debt is expected to peak in 2010 and then decline gradually as the government's financing needs over the medium-term decelerate with the projected improvement in the fiscal position (Text Figure 4$).^{7}$ Thus, over time, the contracting of external project loans will decline and, with basic infrastructure needs addressed, the next stage of addressing the infrastructure gap is likely to be financed through public-private partnerships (PPPs).

- Debt Sustainability Analysis (DSA): The DSA suggests that, with the revised debt ceiling and the projected disbursement profile, the external debt-to-GDP ratio will remain broadly stable at 20 percent and the public debt-to-GDP ratio will renew its downward path after a temporary increase in 2009 (Figures 3 and 4). However, given the high dependency of the Angolan economy on oil, the debt ratios remain very sensitive to oil price volatility. The stress tests show that a noninterest current account shock-in effect, an oil price collapse scenario-

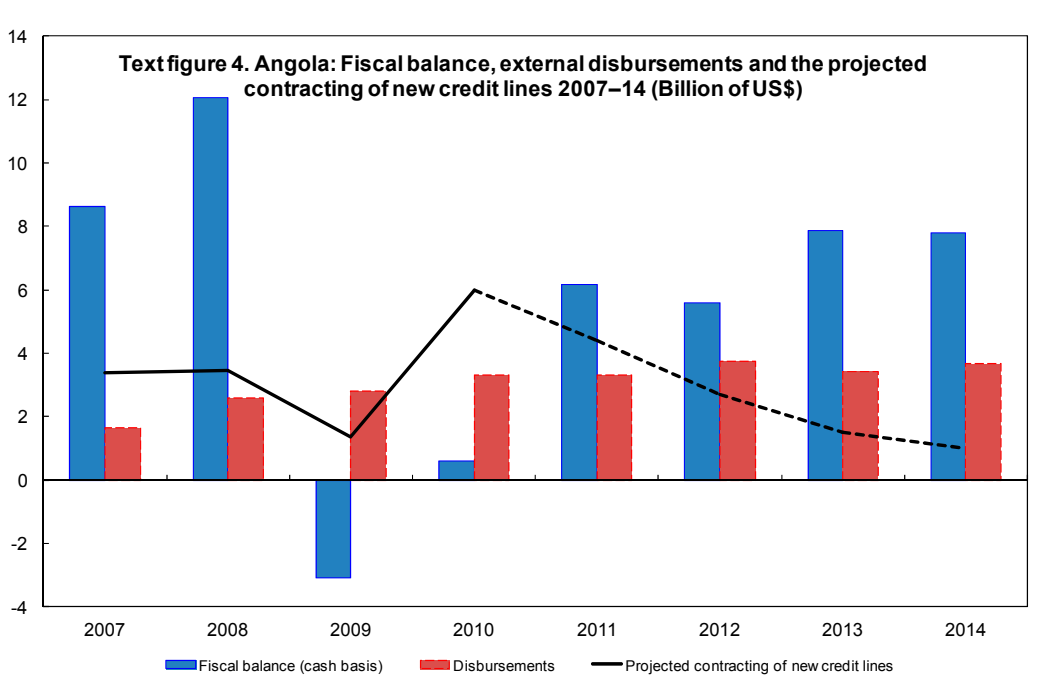

*The projected contracting of new credit lines is based on the current unused framework agreements and the average rate of usage in the recent years.

would lead to a sharp

increase of the external debt ratio by 2015 (on unchanged policies) but this can be considered an unlikely event. Similarly, a real exchange rate shock of 30 percent is also likely to be linked with an oil price collapse. ${ }^{8}$

\footnotetext{
${ }^{6}$ Following staff's advice, the authorities postponed their planned sovereign bond issue (of up to \$4 billion) and accelerated the process of obtaining a credit rating and other preparatory steps that are needed before the bond placement. The authorities are now leaning toward a smaller-size bond issuance.

${ }^{7}$ It is worth noting that given the multi-year nature of most of the projects, there is not a linear correlation between contracting of credit lines and actual disbursements as part of current disbursements are related to past contracts.

${ }^{8}$ Staff calculations based on a partial equilibrium analysis suggest the assumed current account shock would require a drop in oil prices to below $\$ 50$ per barrel.
} 


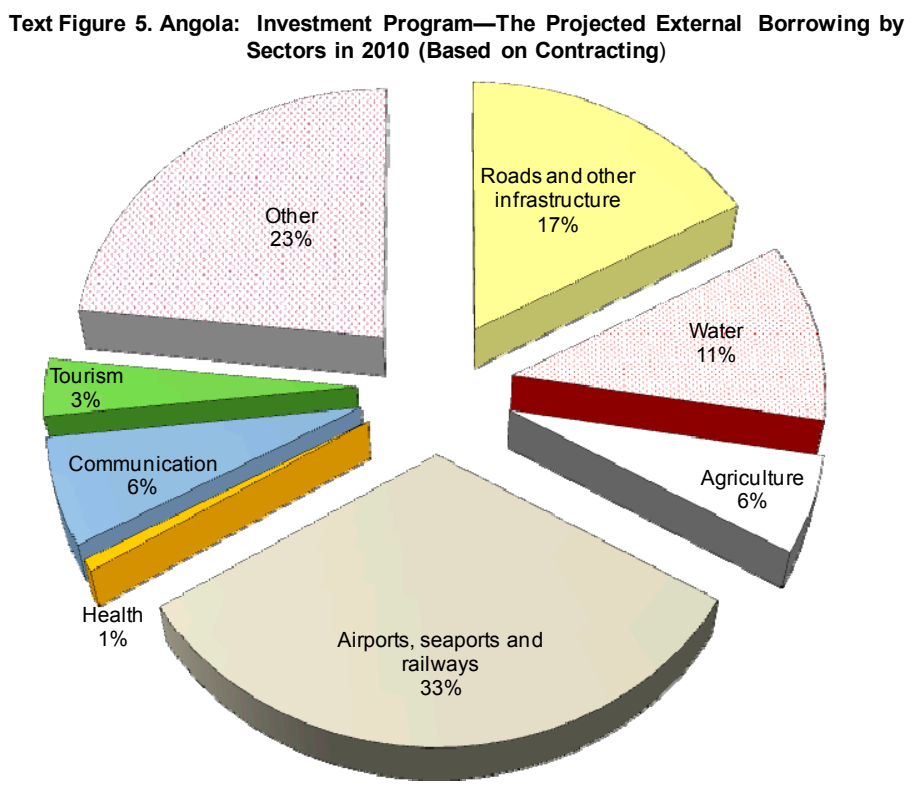

- $\quad$ Project Composition and Quality: The authorities noted that most of the proposed projects are for basic infrastructure (Text Figure 5) destroyed during the civil conflict, which they expect to have high economic rates of return. While a project appraisal framework is being put in place (structural benchmark for September 2010) with the help of the World Bank and the AfDB, most of the project agreements to be concluded have gone through the appraisal process of the export credit agencies in addition to the government's own due-diligence process, which includes approval of each government project by the Angola Court of Accounts. They also noted that a significant number of the projects follow OECD rules. ${ }^{9}$ Projects contracted with China are also subject to a market based bidding process. Going forward, once a project appraisal framework is established by September 2010, all projects should be assessed on that basis with the first assessment report to completed by December (a structural benchmark).

12. The authorities recognize that strengthening public debt management is key to ensuring macroeconomic stability over the medium term and accept the need to a clear and coherent medium term debt strategy (MTDS) that is fully reflected in the budget financing plan (Box 1). They see an urgent need to strengthen the debt management unit at the Ministry of Finance and elevate its role and ensure that it has a seat at the policy table. Under the program, the cabinet is to endorse a package of measures to strengthen debt management capacity by end-September 2010, and to implement selected reforms at the debt management unit by end-December 2010. The cabinet is also expected to approve the main recommendations of the forthcoming MCM TA on developing a sound

\footnotetext{
${ }^{9}$ See http://www.olis.oecd.org/olis/2010doc.nsf/linkto/tad-pg(2010)2.
} 
MTDS (structural benchmark for end-December 2010). Finally, work is to begin on developing a broader asset and liability management framework aided by technical assistance from the Bank and the Fund.

\section{Fiscal Policy and Public Financial Management}

13. The National Assembly in December adopted the 2010 budget, which is in line with the program commitments. The fiscal account in 2010 is projected to improve sufficiently to shift the fiscal balance to a small surplus of 0.7 percent of GDP from a deficit of 4.4 percent of GDP in 2009 (cash basis). Compared to the 2009 outturn, overall spending is projected to remain flat in real terms, reflecting a real decline in current spending of 7 percent and a real increase of 14 percent in capital spending. This, together with the projected increase in non-oil revenues, will keep the 2010 non-oil primary fiscal deficit below the program's level of 47 percent of non-oil GDP. ${ }^{10}$

\begin{tabular}{|l|c|c|c|c|}
\hline \multicolumn{5}{|c|}{ Text Table 1. Angola: Selected Fiscal Indicators (Percent of GDP) } \\
\hline & $\begin{array}{c}\mathbf{2 0 0 9} \\
\text { Supp. }\end{array}$ & $\mathbf{2 0 0 9}$ & \multicolumn{2}{|c|}{$\mathbf{2 0 1 0}$} \\
\cline { 5 - 6 } & Budget & Est. & Prog. & Proj. \\
\hline Revenues & 28.5 & 32.5 & 38.6 & 40.5 \\
\hline - Of which: non-oil tax revenues & 9.0 & 9.5 & 8.2 & 8.5 \\
\hline Expenditures & 41.8 & 41.6 & 37.1 & 35.3 \\
\hline - Of which: current spending & 27.3 & 28.5 & 24.3 & 22.9 \\
\hline - Of which: capital spending & 14.5 & 13.1 & 12.8 & 12.5 \\
\hline Overall fiscal balance (accrual basis) & -13.3 & -9.1 & 1.5 & 5.2 \\
\hline Non-oil primary balance (as a share of non-oil GDP) & -51.8 & -45.9 & -46.8 & -45.9 \\
\hline
\end{tabular}

14. While the 2010 budget is adequate and consistent with the program's goals, budget execution must be assessed frequently to avoid potential slippages. Given the high volatility in oil prices, staff urged the authorities to conduct a formal mid-year review of budget execution to evaluate its adequacy and assess whether additional measures are warranted. Staff also encouraged the authorities to move ahead with the tax reform package that the cabinet recently approved.

\footnotetext{
${ }^{10}$ Based on the permanent income approach, the sustainable non-oil primary deficit in 2010 is around 30 percent of the non-oil GDP. However, over the medium term, the non-oil primary deficit is projected to converge to its sustainable level mainly due to the projected expansion of the non-oil GDP and the government's non-oil revenues.
} 


\section{Box 1. Strengthening Debt Management in Angola}

Background. In view of Angola's planned investment program, which is expected to be largely financed from external sources, and the authorities' intent to start issuing sovereign bonds in the international financial markets, there is an urgent need to strengthen debt management capacity. The current institutional set up has significant weaknesses and lags behind those in other middle-income countries. Management of the public debt is fragmented and divided between various units within both the Ministry of Finance and the BNA; capacity is weak and coordination between the units is limited. There is no leading unit that lays out a coherent medium term debt strategy, including a strategy on the mix of domestic and external borrowing, that monitors potential risks ahead and ensures that current macroeconomic policies are consistent with debt sustainability. Clearly, these weaknesses expose the economy to risks that, if they materialized, could endanger long-term growth.

Medium-Term Debt strategy. Prudent debt management would require a formulation of a coherent medium term debt strategy (MTDS). This will provide a clear and explicit framework within which the authorities can make informed choices on how government financing needs should be met, taking into account the constraints and potential risks. Such a framework will allow for a better assessment of the cost-risk tradeoff while providing a solid platform to evaluate and manage risks. A MTDS will facilitate coordination with fiscal and monetary management, and help to reconcile various objectives and constraints, such as those on market development and balance of payment issues.

Debt Management Unit. Developing and implementing a debt management strategy requires strong coordination mechanisms and an efficient debt management unit (DMU). For the DMU to be effective, it should be guided by: (i) an effective legal framework; (ii) effective institutional arrangements; and (iii) comprehensive and efficient recording of debt. ${ }^{1}$

Implications for Angola. Since most of Angola's debt is contracted by the central government and thus is directly included in the budget process, to build the debt management unit at the Ministry of Finance, which already has some debt monitoring responsibilities. The DMU would be tasked with ensuring the implementation of the MTDS. This may require some revisions to the organic law of the Ministry of Finance in order to set out the overall objectives for debt management, clarify the accountability, and outline the desired reporting and audit requirements.

\footnotetext{
${ }^{1}$ See IMF and World Bank, 2003, Guidelines for Public Debt Management for a fuller discussion.
} 
15. The authorities noted that fiscal policy would continue to be restrictive, with a likely tightening bias in the forthcoming revised 2010 budget. The revised budget, to be finalized in July-August, will include a concrete action plan to clear the stock of domestic arrears. It will also initiate the phasing out of subsidies and other quasi-fiscal operations related to Sonangol and will better prioritize the public investment program. Part of the expenditure savings it makes would be reallocated towards social spending. A social protection scheme will be initiated before subsidies are eliminated to minimize the impact on the poor and vulnerable.

\section{The authorities continue to make steady progress in revamping their} management of public finances, but more needs to be done, particularly with regard to fiscal transparency. The authorities have published Sonangol's 2007 and 2008 audited financial statements on its website in-April 2010 (a prior action for the first SBA review). The authorities noted that design of the key elements of the planned sovereign wealth fund is in its final stage and a draft will be submitted to the cabinet by end-June 2010. Setting up a well-designed sovereign wealth fund should help strengthen asset management and support implementation of a counter-cyclical fiscal policy. Additionally, the authorities reaffirmed their commitment to comply with the program's structural benchmarks, including publishing the central government's quarterly budget execution reports and the reporting and publishing of major state-owned enterprises (SOEs) financial operations by June 2010.

\section{Program Monitoring, SAFeguard And Other Issues}

17. Precautionary SBA: Given Angola's improving external position, the mission sought the authorities' views on moving toward a precautionary SBA. The authorities took the position that the external outlook remained uncertain, that the import coverage ratio and the coverage of short-term liabilities remained uncomfortably low, and that they wished to rebuild reserves in a speedy manner. Staff is of the view that were the external overperformance to persist over the first half of 2010, then serious consideration should be given to converting the current SBA into a precautionary arrangement. ${ }^{11}$

\section{The technical definition of the performance criterion on net international} reserves (NIR) has been modified. During the mission, staff and the authorities jointly conducted an analysis of the BNA's international reserves to measure accurately the program definition of NIR as of end-December $2009 .{ }^{12}$ On that basis, staff proposed and

\footnotetext{
${ }^{11}$ Preliminary information for the first quarter (including the evolution of net international reserves) suggests that developments in early 2010 are broadly in line with the program.

${ }^{12}$ Key problems identified included the illiquidity of some foreign assets managed by foreign asset managers, the presence of investment commitments by the BNA to these asset managers, and BNA guarantees of selected government debts that could constitute encumbrance on reserves. While the BNA has guarantees of about $\$ 8.8$ billion in off-balance sheet commitments, related to borrowings contracted by the Ministry of Finance,
} 
the authorities accepted a streamlined definition of program NIR that would make it operationally easier to track over time. This includes dropping an adjuster on unconfirmed asset balances. A special NIR review is to be carried out as a prior action for the second review.

19. Staff supports the requested waivers by the authorities. Staff supports the authorities' requests for a waiver of nonobservance of the continuous performance criterion on external arrears as the nonobservance is negligible and the authorities have taken the remedial action to strengthen the Treasury's payment system. Staff also supports a request for a waiver of non-observance on the performance criterion for end-March 2010 on the non-accumulation of domestic arrears as the authorities have also strengthened treasury operations to avoid further accumulation of domestic arrears (Extended LOI, I 13). ${ }^{13}$ For the other four performance criteria, in light of the unavailability of the information necessary to assess observance at end-March 2010, staff supports the request of the waiver of applicability as the program is successfully implemented and there is no clear evidence that the rest of performance criteria will not be met. The arrangement is being rephased by combining the second and third program reviews largely due to logistics issues related to the significant delay in completing the first program review.

20. Safeguard issues: A first-time safeguards assessment of the BNA conducted in January 2010 confirmed significant safeguards risks. Some elements of the BNA safeguards framework have been strengthened in recent years; the BNA is subject to annual external audits by a reputable audit firm and has taken steps to address the audit qualifications and to accelerate the 2009 annual audit. However, weak governance and transparency practices, including lack of publication of the audited accounts, remain a concern. Key oversight organs at the BNA (the Audit Board and the Advisory Council) are not functional, the control framework in the reserves management area needs strengthening, and the 2008 audit was completed with a significant delay in March 2010. The internal audit function also falls short of international standards and does not cover certain key operations. Priority safeguards recommendations are incorporated in the program (Table 2 of the extended LOI), and the authorities noted that these measures were broadly in line with their own institutional modernization strategy.

\section{Anti-money laundering and combating the financing of terrorism (AML/CFT):}

The authorities recognize the need to address significant weaknesses in the existing

staff and the authorities agreed that these do not constitute encumbrance of reserves at this juncture: such guarantees have never been called upon before, and the relevant borrowings are collateralized with oil receipts through escrow accounts.

${ }^{13}$ With regard to the performance criterion on domestic arrears, we are anticipating that the target was missed by a margin of some $60-100$ billion kwanzas. 
AML/CFT framework. To this end, they intend to enact AML/CFT legislation that meets international standards and to implement preventive measures in the financial sector (including procedures for reporting suspicious transactions). They have also committed to creating the institutions necessary to support the AML/CFT structure, including a financial intelligence unit (FIU).

\section{Staff Appraisal}

22. Overview. The reforms under the SBA are beginning to bear fruit in line with key program goals and the heavy market pressures that were evident when the program was negotiated have been substantially eased. Signs of economic recovery are emerging as the external environment becomes more favorable and market confidence is improving. At the same time, there are still serious challenges ahead that require decisive policy actions.

23. Monetary policy. Tight monetary policy is needed to ease pressure on the exchange rate while supporting the program's goal of rebuilding reserves. Removing government bonds and other securities as eligible assets for meeting reserve requirement, while issuing more attractive BNA notes will improve liquidity management. Moreover, the government will likely need to accept higher interest rates in its auctions of government bonds if it is to meet its domestic financing needs and prevent arrears accumulation. Staff welcome the steps taken by the BNA on strengthening banking supervision, including amending provisioning regulation, strengthening the management of credit risk for foreign currency loans and developing off-site supervisory tools.

24. Exchange rate. The renewal of the auction system has facilitated significant exchange rate adjustment and eased pressures in the foreign exchange market. However, more must be done to bring about a fully market determined exchange rate. Improving the transparency of the auction process, including by introducing a well-understood "outliers" policy, and facilitating the unification of the secondary and the parallel markets are key elements in this regard. It will also be key to set foreign exchange sales at a level that is consistent with the SBA's goal of rebuilding reserves.

25. Debt management. While the upward revision in the external debt ceiling is significant, staff can go along with it on the grounds that it poses no macroeconomic risks and while allowing Angola, with its relatively low level of debt and large oil reserves, to press ahead in addressing its large infrastructure gap. Staff also urges the government to stay within the new external debt ceiling. Strengthening public debt management should be a priority, particularly in view of the increased borrowing levels and the authorities' intention to proceed with a debut sovereign bond issue. Efforts should be focused on articulating a coherent medium-term debt strategy, to be fully integrated in the budget process, and strengthen Angola's own project appraisal capability. It will also be necessary to redefine the role of debt managers so that they have a policy oriented focus, rather than a 
mere recording/debt servicing function, and to ensure that they have a seat at the policy table to ensure that debt management issues are fully factored into the policy debate.

26. Fiscal policy. Implementation of the fiscal adjustment plan for 2010 is key to achieving program objectives. To avoid slippages, the authorities should conduct a formal mid-year review of budget execution and adopt any necessary additional measures. Staff welcomes the authorities' commitment to clear all domestic arrears in the forthcoming revised 2010 budget. The plans to phase out quasi-fiscal operations related to Sonangol in the revised budget are also welcome.

27. Public financial management. The authorities continue to make steady progress in revamping their public financial management. Their commitment to enhance fiscal transparency, especially in the oil sector, has been illustrated by the publication of Sonangol's 2007 and 2008 audited financial statements. Establishing a well-designed sovereign wealth fund will be instrumental in strengthening asset management and supporting the implementation of a counter-cyclical fiscal policy.

28. Safeguards assessment. The high priority recommendations of the recent safeguards assessment of the BNA have been incorporated into the program to reduce safeguard risks. These recommendations are in line with the BNA's own modernization program.

29. Risks. The key risk to the Angolan economy is the potential sluggishness of the global recovery and the associated easing of oil prices. A sharp decline in oil prices would put heavy pressures on the fiscal and external positions and endanger the program's objective of rebuilding international reserves but this is far from the baseline scenario outlined in the April 2010 WEO. That said, the authorities need to closely monitor fiscal and external developments and recalibrate policies as needed to ensure that the program remains on track.

30. The Angolan authorities have, to date, shown a firm commitment to the program as is reflected in their ambitious fiscal adjustment measures. Staff recommends completion of the first SBA review and supports granting of the waivers that the authorities have requested. 
Figure 1. Angola in a Cross-Country Perspective, Based on Selected Group of Oil Exporting Countries (Average for 2004-08 ${ }^{1}$ )

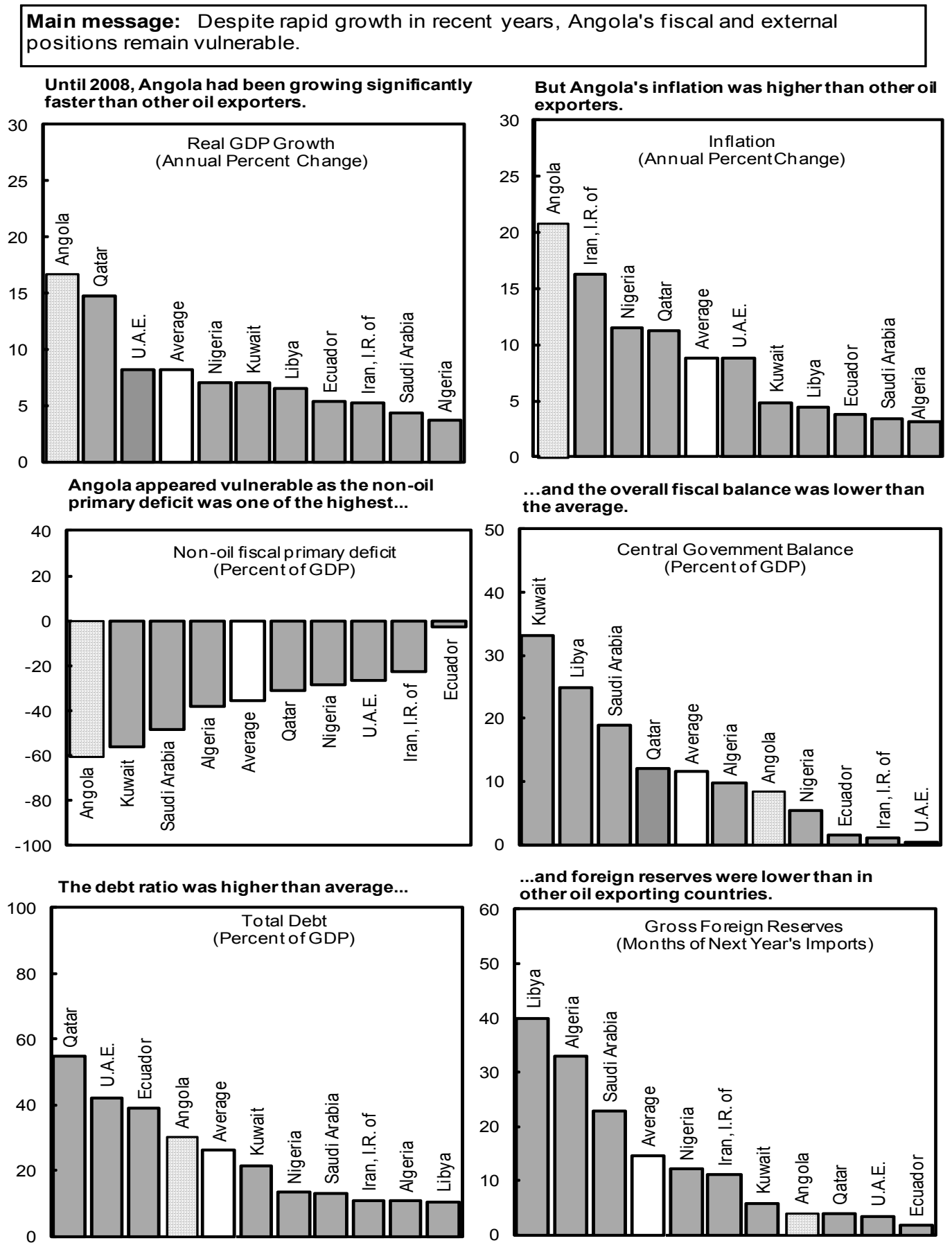

Sources: World Economic Outlook and International Financial Statistics.

${ }^{1}$ U.A.E.: United Arab Emirates. 
Figure 2. Angola: Recent Economic Trends

Main Message: Economic activity and the fiscal balance are projected to recover in 2010, after being buffeted by severe terms of trade shocks that turned the fiscal balance into deficit.

Real GDP is projected to rebound in $2010 \ldots$

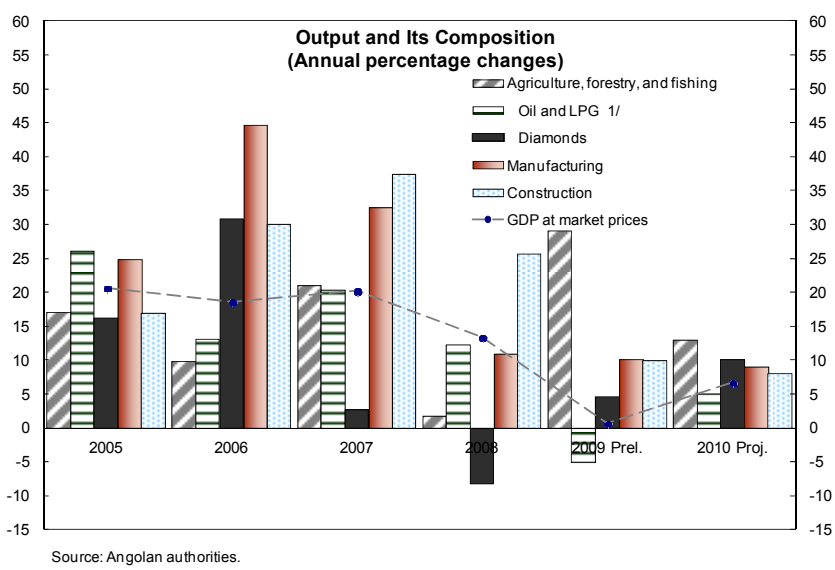

The fiscal balance turned into deficit in 2009, but is projected to record a small surplus in $2010 \ldots$

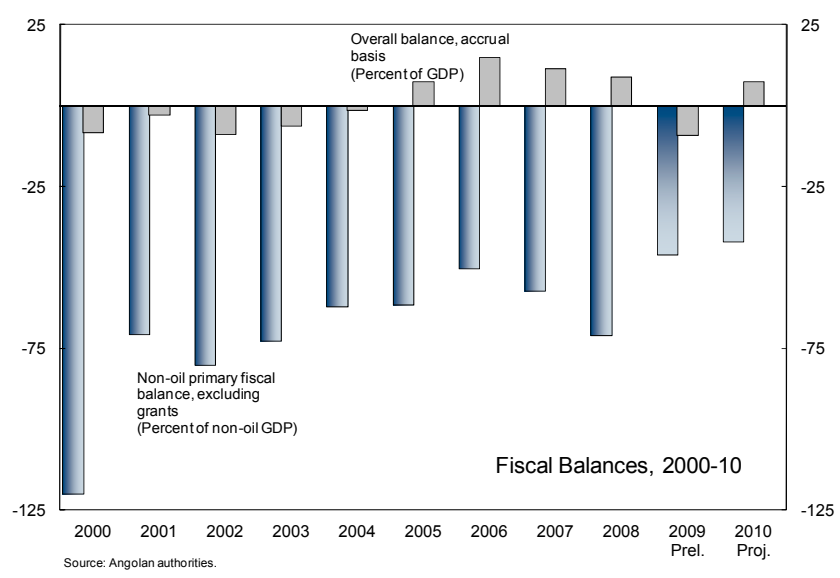

...largely reflecting the recovery in oil production.

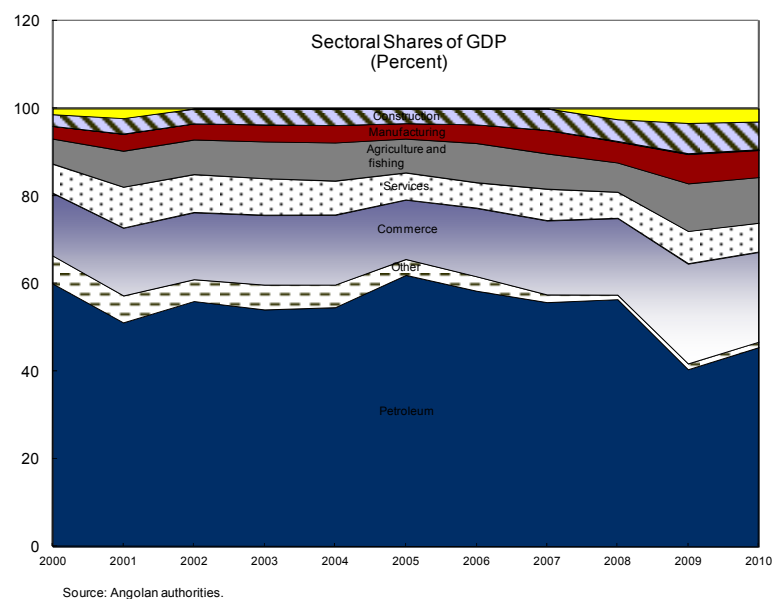

...while expenditures continue to decline as a percent of non-oil GDP.

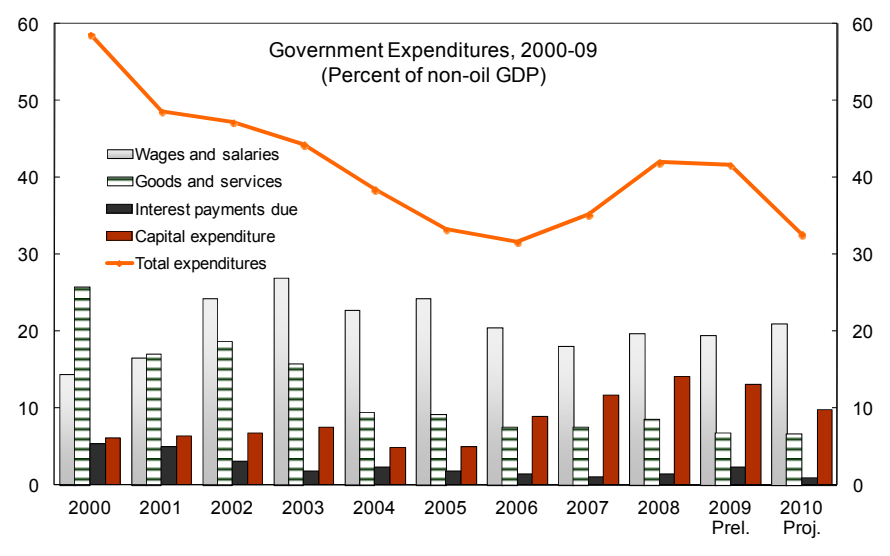

Source: Angolan authorities. 
Figure 2. Angola: Recent Economic Trends (continued)

Main Message: The nominal exchange has depreciated and dollarization remains high. To support the exchange rate policy, the BNA has tightened liquidity conditions.

The nominal exchange rate has depreciated...

Nominal Exchange Rates: January 2007-December 2009

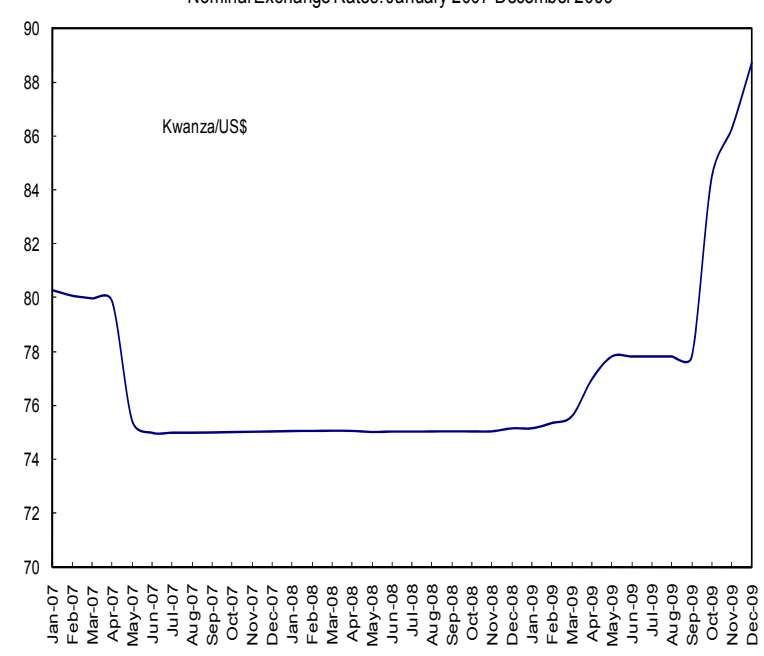

To support the exchange rate policy, the BNA has tightened liquidity conditions...

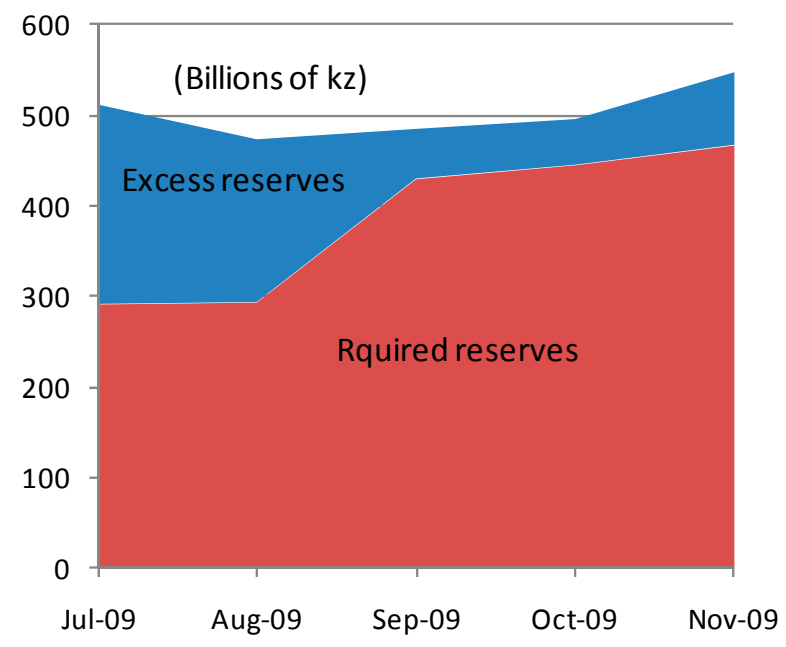

....and dollarization has stabilized at a high level.

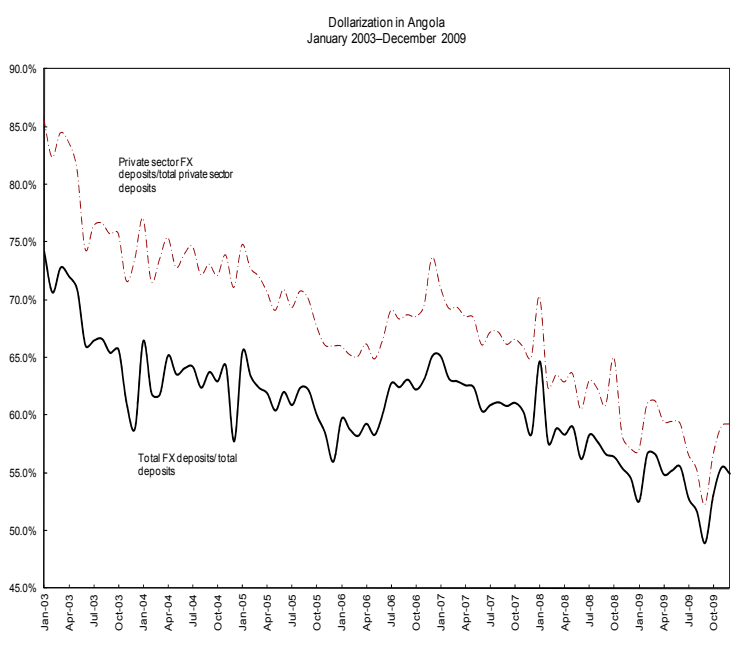

...but there are still pockets of excess liquidity in the banking system.

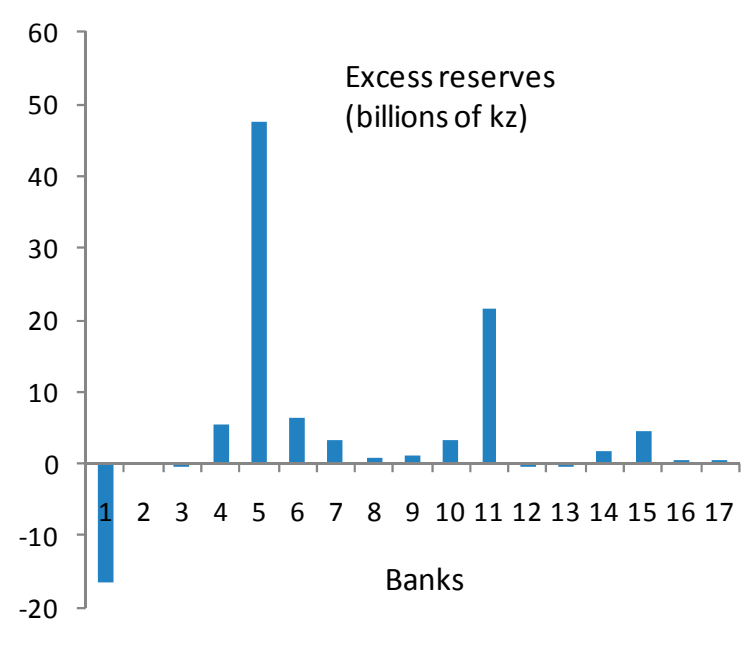


Figure 2. Angola: Recent Economic Trends (continued)

Main message: Inflation has remained stable despite the exchange rate depreciation. Money and credit growth has moderated as the BNA has tightened its monetary policy stance.

Inflation has remained stable despite the exchange rate depreciation.

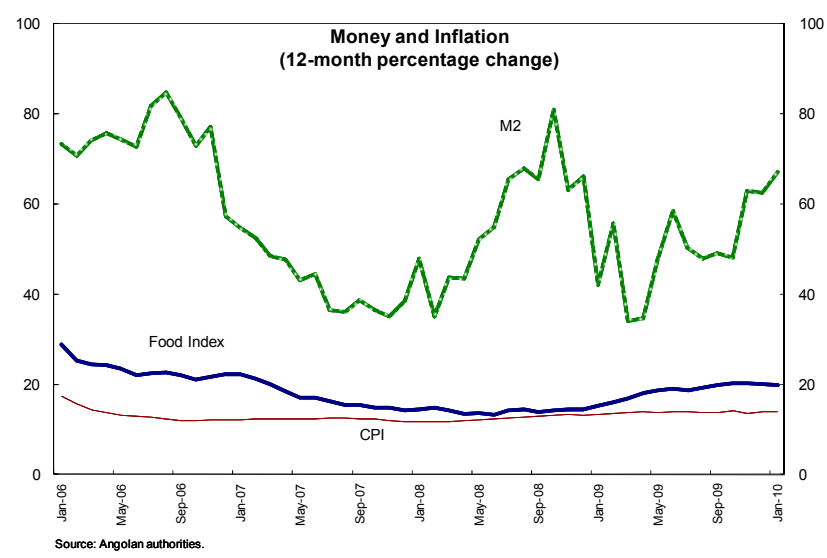

Credit growth has moderated in 2009, but still outpacing nominal GDP...

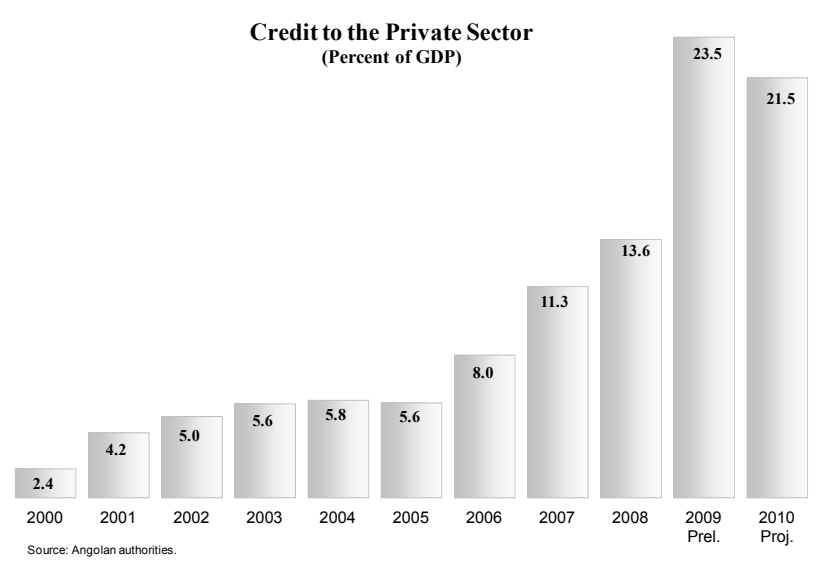

The BNA has tightened monetary policy by increasing its policy rate.

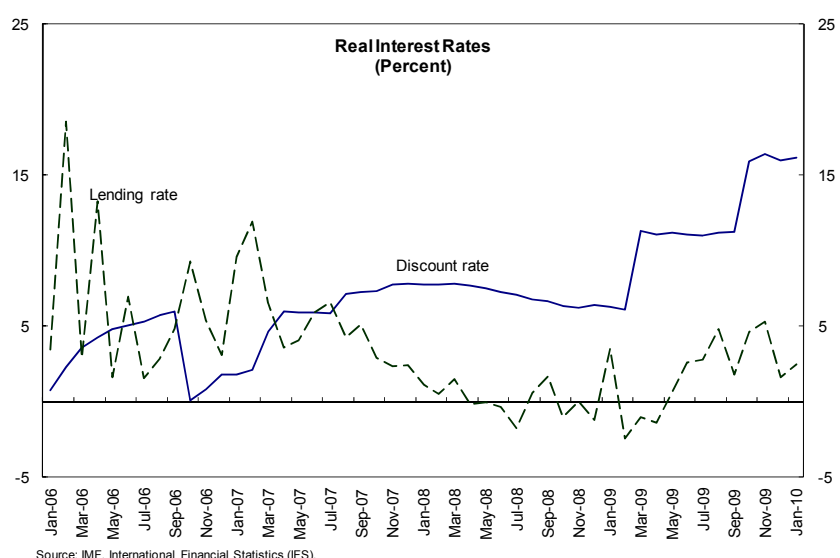

...with individuals the main borrowers.

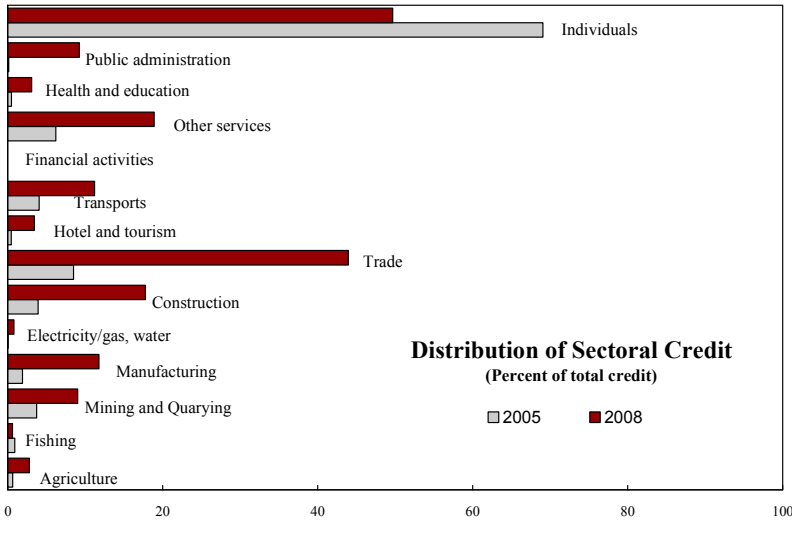


Figure 2. Angola: Recent Economic Trends (concluded)

Main message: The recovery of oil prices and the exchange rate depreciation in the second half of 2009 have stabilized international reserves and set the stage for a current account reversal in 2010.

The real effective exchange rate has depreciated and net international reserves have stabilized.
The current account balance is projected to record a small surplus in 2010.
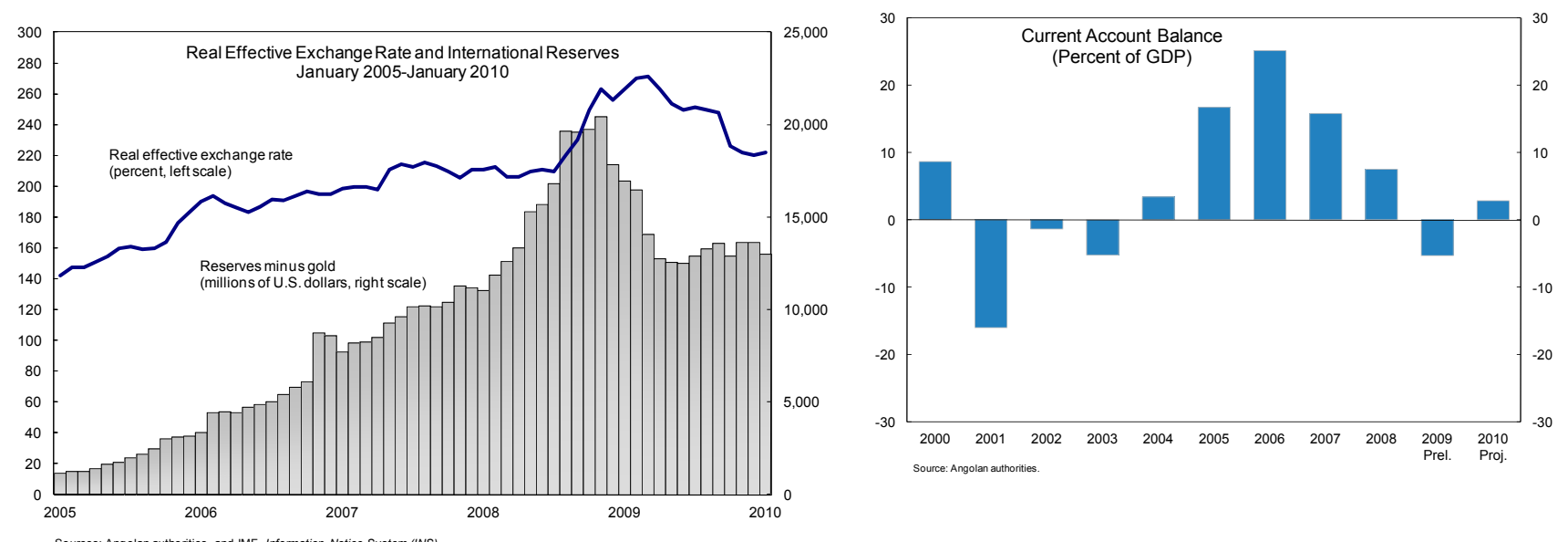

Angola is among the least competitive oil producers.

Global Competitiveness Index for Selected Economies, 2007

(a) Overall Index

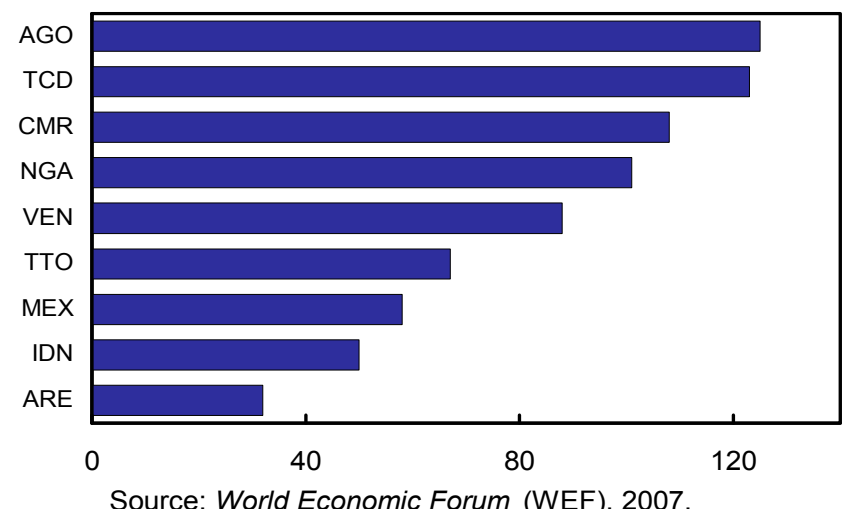

(b) Sub-Indices

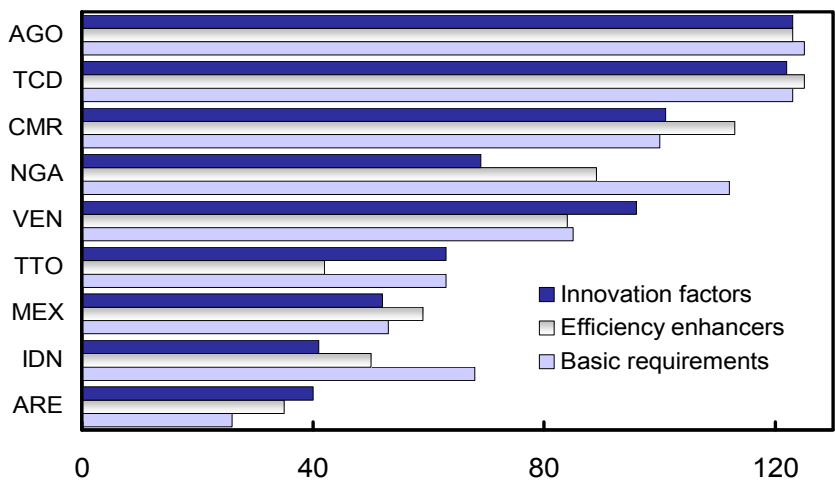

Note: Basic requirements=infrastructure, institutions, and macroeconomic performance; Efficiency enhancers=higher education and training, market efficiency, technology adaption; Innovation factors=business sophistication, innovation. 
Figure 3. Angola: External Debt Sustainability: Bound Tests ${ }^{1}$ (External Debt in Percent of GDP)

Main message: With the favorable external conditions and the projected acceleration of GDP growth, external debt dynamics are projected to improve and the debt ratio are expected to renew their downward trajectory.
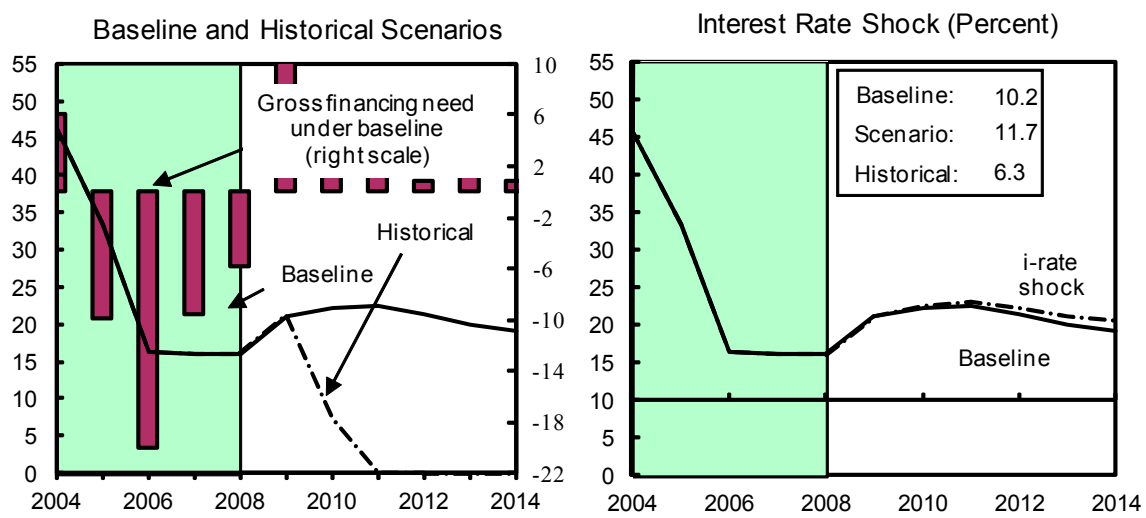

Growth Shock (Percent per Year)

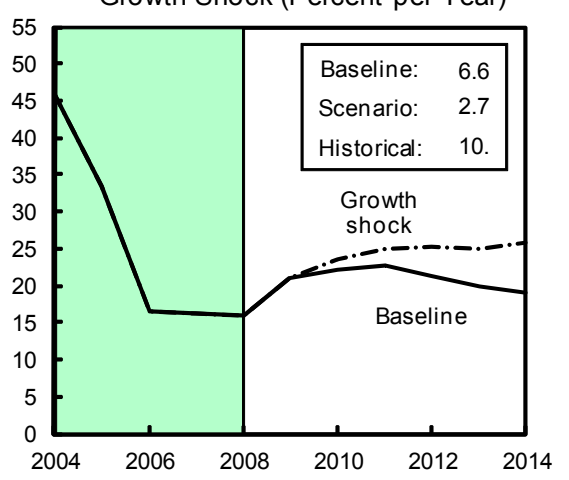

Non-interest Current Account Shock

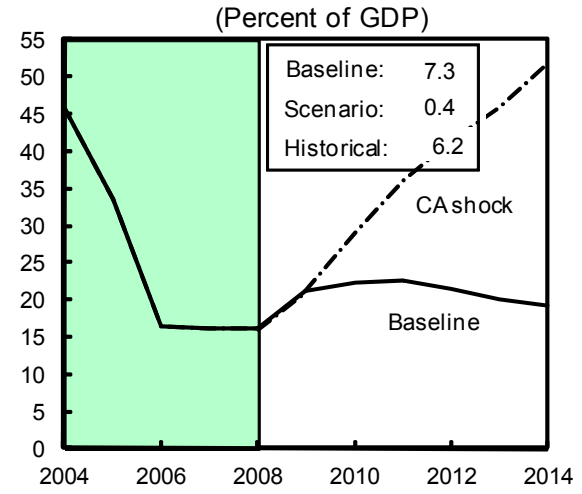

Combined Shock 2
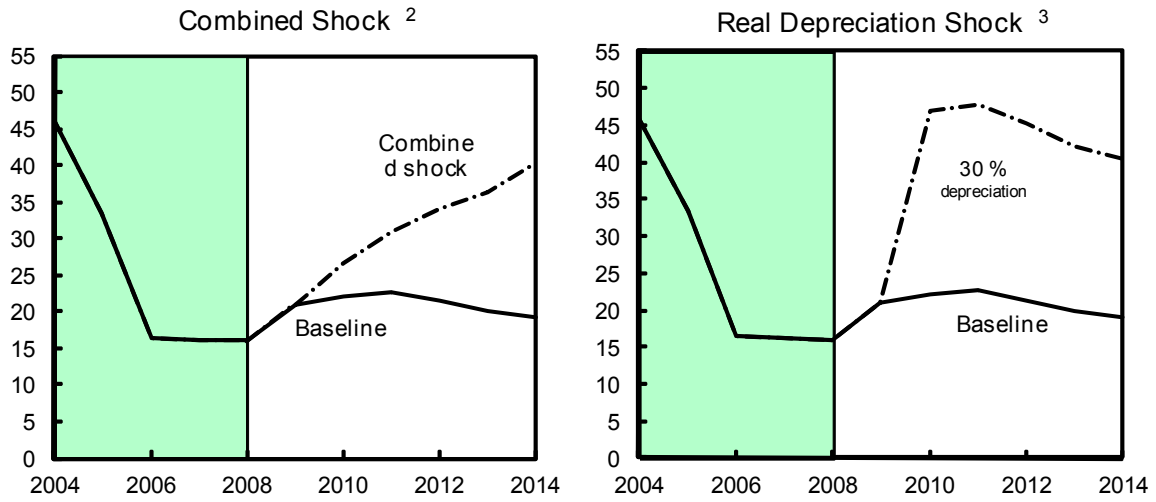

Sources: International Monetary Fund, Country desk data, and staff estimates.

${ }^{1}$ Shaded areas represent actual data. Individual shocks are permanent one-half standard deviation shocks. Figures in the boxes represent average projections for the respective variables in the baseline and scenario being presented. Ten-year historical average for the variable is also shown.

${ }_{2}^{2}$ Permanent $1 / 4$ standard deviation shocks applied to real interest rate, growth rate, and current account balance.

${ }^{3}$ One-time real depreciation of 30 percent occurs in 2010 
Figure 4. Angola: Public Debt Sustainability: Bound Tests 1 (Public Debt in Percent of GDP)

Main message: With the favorable external conditions and the projected acceleration of GDP growth, public debt dynamics are projected to improve and the debt ratio are expected to renew its downward trajectory.
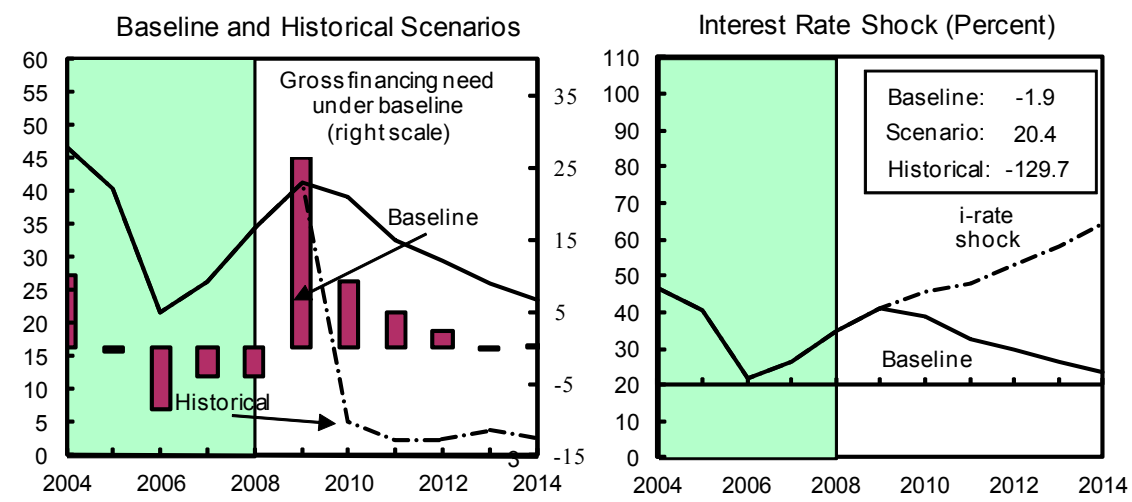

Growth Shock (Percent per Year)

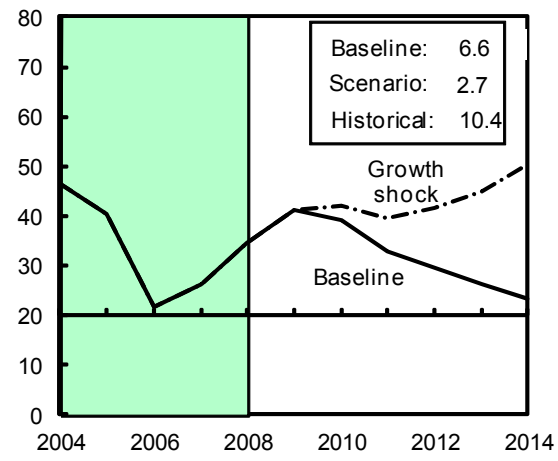

Primary Balance Shock (Percent of GDP) and no Policy Change Scenario (Constant Pimary Balance)
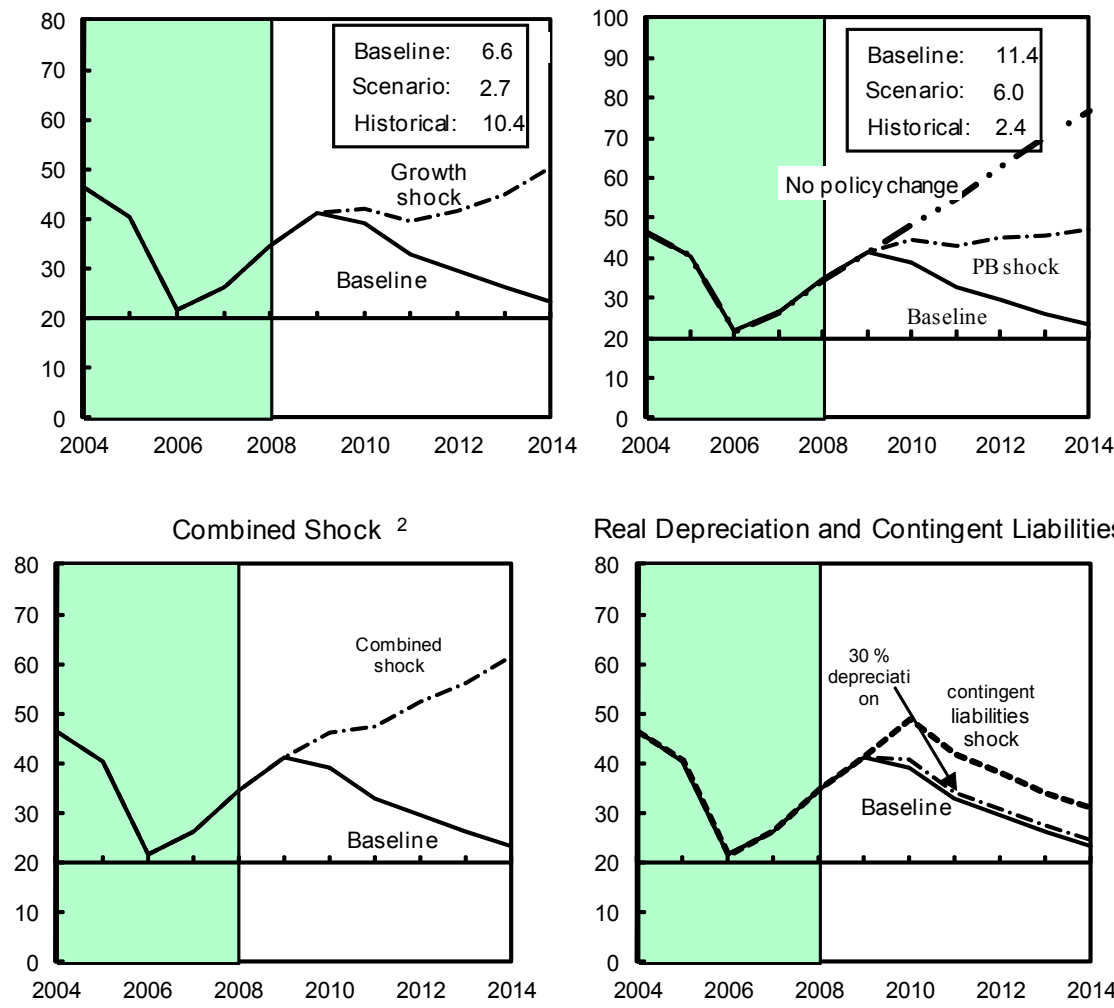

Real Depreciation and Contingent Liabilities Shocks

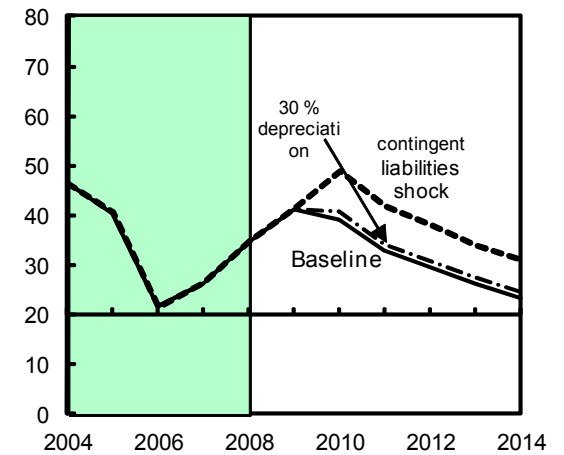

Sources: International Monetary Fund, country desk data, and staff estimates.

1 Shaded areas rep resent actual data. Individual shocks are permanent one-half standard deviation shocks. Figures in the boxes represent average projections for the respective variables in the baseline and scenario being presented. Ten-year historical average for the variable is also shown.

${ }^{2}$ Permanent $1 / 4$ stan dard deviation shocks ap plied to real interest rate, growth rate, and primary balance.

${ }^{3}$ One-time real depreciation of 30 percent and 10 percent of GDP shock to contingent liabilities occur in 2010 , with real depreciation defined as nominal depreciation (measured by percentage fall in dollar value of local curren cy) minus domestic inflation (based on GDP deflator). 
Table 1. Angola: Selected Economic and Financial Indicators, 2007-15

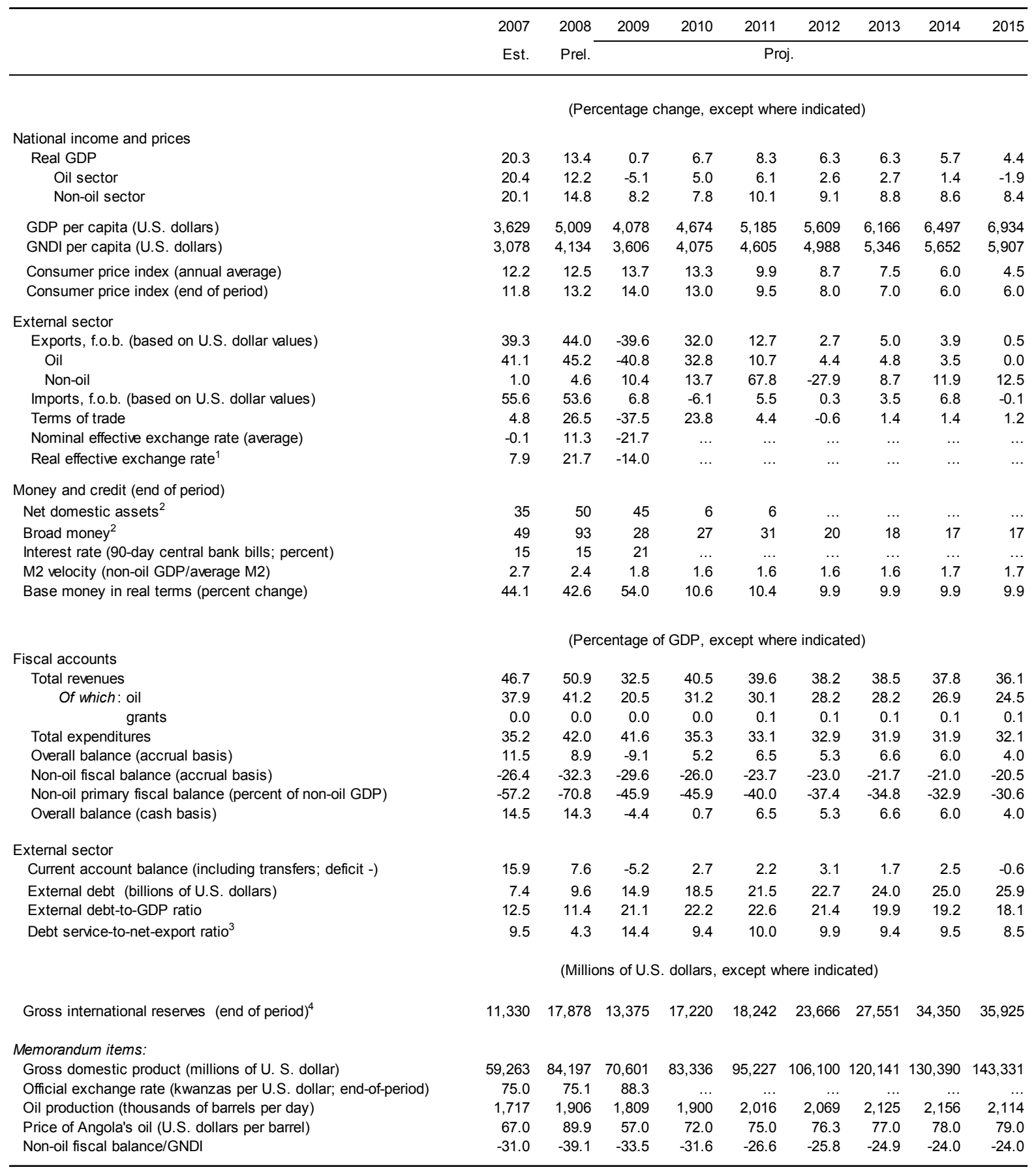

Sources: Angolan authorities, and IMF staff estimates and projections.

${ }^{1}$ End of period. A positive sign denotes appreciation.

${ }^{2}$ As percentage of beginning-of-period M3.

${ }^{3}$ Percent of exports of goods and services.

${ }^{4}$ Includes government deposits in overseas accounts and less liquid assets. 
Table 2a. Angola: Summary of Government Operations, 2006-11

(Billions of kwanzas; unless otherwise indicated)

\begin{tabular}{|c|c|c|c|c|c|c|c|}
\hline & 2006 & 2007 & 2008 & 2009 & 2010 & 2010 & 2011 \\
\hline & & & Est. & Est. & Prog. & Proj. & Proj. \\
\hline Revenue & $1,684.9$ & $2,124.7$ & $3,217.4$ & $1,847.9$ & $2,850.6$ & $3,071.2$ & $3,532.3$ \\
\hline Tax revenue & $1,577.9$ & $2,052.8$ & $3,070.2$ & $1,703.7$ & $2,788.7$ & $3,009.3$ & $3,453.9$ \\
\hline Oil & $1,350.6$ & $1,722.0$ & $2,601.9$ & $1,164.8$ & $2,182.4$ & $2,362.1$ & $2,687.5$ \\
\hline Non-oil & 227.3 & 330.8 & 468.3 & 539.0 & 606.3 & 647.2 & 766.4 \\
\hline Nontax revenue & 107.0 & 69.6 & 145.3 & 142.9 & 60.0 & 60.0 & 69.0 \\
\hline Grants & 0.0 & 2.3 & 1.9 & 1.3 & 1.9 & 1.9 & 9.4 \\
\hline Expenditures & $1,146.7$ & $1,597.3$ & $2,653.8$ & $2,363.4$ & $2,737.4$ & $2,679.0$ & $2,949.4$ \\
\hline Current expenditure & 823.8 & $1,049.3$ & $1,761.2$ & $1,620.1$ & $1,791.6$ & $1,733.2$ & $1,913.8$ \\
\hline Personnel & 310.2 & 364.5 & 543.0 & 660.2 & 843.6 & 866.6 & 923.7 \\
\hline Goods and services & 274.5 & 320.7 & 539.1 & 383.3 & 503.1 & 499.2 & 550.9 \\
\hline Interest payments due & 53.6 & 51.0 & 93.9 & 130.0 & 137.3 & 75.3 & 116.7 \\
\hline Domestic & 9.7 & 16.3 & 60.2 & 90.3 & 100.5 & 45.3 & 85.7 \\
\hline External & 44.0 & 34.7 & 33.8 & 39.7 & 36.8 & 30.0 & 31.0 \\
\hline Transfers & 185.4 & 313.1 & 585.2 & 446.6 & 307.6 & 292.1 & 322.4 \\
\hline Of which: subsidies (oil and utilities) & 127.1 & 221.1 & 443.4 & 356.3 & 207.9 & 186.7 & 227.7 \\
\hline Capital and other & 322.9 & 548.0 & 892.6 & 743.3 & 945.8 & 945.8 & $1,035.6$ \\
\hline Capital expenditure & 322.9 & 548.0 & 892.6 & 743.3 & 945.8 & 945.8 & $1,035.6$ \\
\hline Discrepancy & 0.0 & 0.0 & 0.0 & 0.0 & 0.0 & 0.0 & 0.0 \\
\hline Overall balance (accrual basis) & 538.2 & 527.5 & 561.7 & -515.5 & 113.3 & 392.2 & 582.9 \\
\hline Change in payments arrears (net) & -298.6 & 136.8 & 344.3 & 266.9 & -235.3 & -338.7 & 0.0 \\
\hline Domestic & -298.6 & 113.8 & 332.1 & 303.4 & -200.0 & -303.4 & 0.0 \\
\hline External interest & 0.0 & 23.0 & 12.2 & -36.4 & -36.4 & -35.3 & 0.0 \\
\hline Overall balance (cash basis) & 239.6 & 664.3 & 906.0 & -248.5 & -122.1 & 53.5 & 582.9 \\
\hline Financing & -239.6 & -664.3 & -906.0 & 248.5 & 122.1 & -53.5 & -582.9 \\
\hline Oil bonus (net) & 80.3 & 0.0 & 0.0 & 0.0 & 0.0 & 0.0 & 0.0 \\
\hline External financing (net) & -33.4 & 38.0 & 41.3 & 137.3 & 32.4 & 115.2 & 20.8 \\
\hline Borrowing (net) & -33.4 & 38.0 & 41.3 & 137.3 & 32.4 & 115.2 & 20.8 \\
\hline Disbursements & 262.3 & 127.6 & 194.6 & 225.7 & 283.7 & 300.2 & 310.7 \\
\hline Amortization & -295.7 & -89.6 & -153.2 & -88.4 & -251.3 & -185.0 & -289.9 \\
\hline Short-term borrowing, net & 0.0 & 0.0 & 0.0 & 0.0 & 0.0 & 0.0 & 0.0 \\
\hline Debt relief & 0.0 & 0.0 & 0.0 & 0.0 & 0.0 & 0.0 & 0.0 \\
\hline Domestic financing (net) & -287.2 & -702.3 & -947.4 & 111.2 & 89.7 & -168.7 & -603.7 \\
\hline Bank financing & -336.7 & 55.9 & -478.5 & 622.0 & 0.0 & -127.0 & -301.9 \\
\hline Non-bank financing ${ }^{2}$ & 124.0 & -758.2 & -468.8 & -510.8 & 89.7 & -42.7 & -301.9 \\
\hline \multicolumn{8}{|l|}{ Memorandum items: } \\
\hline External public debt (end of period) & 594.0 & 737.3 & $1,014.1$ & $1,633.8$ & $1,640.4$ & $1,640.4$ & $2,125.6$ \\
\hline Non-oil taxes & 227.3 & 402.7 & 468.3 & 539.0 & 606.3 & 647.2 & 766.4 \\
\hline Non-oil fiscal balance & -812.4 & $-1,194.6$ & $-2,038.3$ & $-1,680.2$ & $-2,069.2$ & $-1,969.9$ & $-2,104.6$ \\
\hline Non-oil primary fiscal balance (excluding grants) & -758.8 & $-1,143.6$ & $-1,946.2$ & $-1,551.6$ & $-1,933.8$ & $-1,734.3$ & $-1,997.3$ \\
\hline Nominal GDP & 3,630 & 4,546 & 6,374 & $5,677.3$ & $7,385.1$ & $7,581.4$ & $8,917.9$ \\
\hline Non-oil GDP & 1,509 & 2,009 & 2,748 & $3,377.8$ & $4,134.2$ & $4,127.6$ & $4,988.4$ \\
\hline
\end{tabular}

Sources: Angolan authorities and IMFstaff estimates and projections. 
Table 2b. Angola: Summary of Government Operations, 2006-11

(Percent of GDP; unless otherwise indicated)

\begin{tabular}{|c|c|c|c|c|c|c|c|}
\hline & 2006 & 2007 & 2008 & 2009 & 2010 & 2010 & 2011 \\
\hline & & & Est. & Est. & Prog. & Proj. & Proj. \\
\hline Revenue & 46.4 & 46.7 & 50.5 & 32.5 & 38.6 & 40.5 & 39.6 \\
\hline Tax revenue & 43.5 & 45.2 & 48.2 & 30.0 & 37.8 & 39.7 & 38.7 \\
\hline Oil & 37.2 & 37.9 & 40.8 & 20.5 & 29.6 & 31.2 & 30.1 \\
\hline Non-oil & 6.3 & 7.3 & 7.3 & 9.5 & 8.2 & 8.5 & 8.6 \\
\hline Nontax revenue & 2.9 & 1.5 & 1.0 & 2.5 & 0.8 & 0.8 & 0.8 \\
\hline Grants & 0.0 & 0.1 & 0.0 & 0.0 & 0.0 & 0.0 & 0.1 \\
\hline Expenditures & 31.6 & 35.1 & 41.6 & 41.6 & 37.1 & 35.3 & 33.1 \\
\hline Current expenditures & 22.7 & 23.1 & 27.6 & 28.5 & 24.3 & 22.9 & 21.5 \\
\hline Personnel & 8.5 & 8.0 & 8.5 & 11.6 & 11.4 & 11.4 & 10.4 \\
\hline Goods and services & 7.6 & 7.1 & 8.5 & 6.8 & 6.8 & 6.6 & 6.2 \\
\hline Interest payments due & 1.5 & 1.1 & 1.5 & 2.3 & 1.9 & 1.0 & 1.3 \\
\hline Domestic & 0.3 & 0.4 & 0.9 & 1.6 & 1.4 & 0.6 & 1.0 \\
\hline External & 1.2 & 0.8 & 0.5 & 0.7 & 0.5 & 0.4 & 0.3 \\
\hline Transfers & 5.1 & 6.9 & 9.2 & 7.9 & 4.2 & 3.9 & 3.6 \\
\hline Of which: subsidies (oil and utilities) & 3.5 & 4.9 & 7.0 & 6.3 & 2.8 & 2.5 & 2.6 \\
\hline Capital and other & 8.9 & 12.1 & 14.0 & 13.1 & 12.8 & 12.5 & 11.6 \\
\hline Capital expenditure & 8.9 & 12.1 & 14.0 & 13.1 & 12.8 & 12.5 & 11.6 \\
\hline Overall balance (accrual basis) & 14.8 & 11.6 & 8.8 & -9.1 & 1.5 & 5.2 & 6.5 \\
\hline Change in payments arrears (net) & -8.2 & 3.0 & 5.4 & 4.7 & -3.2 & -4.5 & 0.0 \\
\hline Domestic & -8.2 & 2.5 & 5.2 & 5.3 & -2.7 & -4.0 & 0.0 \\
\hline External interest & 0.0 & 0.5 & 0.2 & -0.6 & -0.5 & -0.5 & 0.0 \\
\hline Overall balance (cash basis) & 6.6 & 14.6 & 14.2 & -4.4 & -1.7 & 0.7 & 6.5 \\
\hline Financing & -6.6 & -14.6 & -14.2 & 4.4 & 1.7 & -0.7 & -6.5 \\
\hline Oil bonus (net) & 2.2 & 0.0 & 0.0 & 0.0 & 0.0 & 0.0 & 0.0 \\
\hline External financing (net) & -0.9 & 0.8 & 0.6 & 2.4 & 0.4 & 1.5 & 0.2 \\
\hline Borrowing (net) & -0.9 & 0.8 & 0.6 & 2.4 & 0.4 & 1.5 & 0.2 \\
\hline Disbursements & 7.2 & 2.8 & 3.1 & 4.0 & 3.8 & 4.0 & 3.5 \\
\hline Amortization & -8.1 & -2.0 & -2.4 & -1.6 & -3.4 & -2.4 & -3.3 \\
\hline Short-term borrowing, net & 0.0 & 0.0 & 0.0 & 0.0 & 0.0 & 0.0 & 0.0 \\
\hline Debt relief & 0.0 & 0.0 & 0.0 & 0.0 & 0.0 & 0.0 & 0.0 \\
\hline Domestic financing (net) & -7.9 & -15.4 & -14.9 & 2.0 & 1.2 & -2.2 & -6.8 \\
\hline Bank financing & -9.3 & 1.2 & -7.6 & 11.0 & 0.0 & -1.7 & -3.4 \\
\hline Nonbank financing ${ }^{1}$ & 3.4 & -16.7 & -7.4 & -9.0 & 1.2 & -0.6 & -3.4 \\
\hline \multicolumn{8}{|l|}{ Memorandum items: } \\
\hline External public debt (end of period) & 16.4 & 16.2 & 16.0 & 21.1 & 19.9 & 22.2 & 22.6 \\
\hline Non-oil taxes (percent of non-oil GDP) & 15.1 & 20.0 & 17.0 & 16.0 & 14.7 & 15.7 & 15.4 \\
\hline Non-oil fiscal balance & -22.4 & -26.3 & -32.0 & -29.6 & -28.0 & -26.0 & -23.6 \\
\hline Non-oil fiscal balance (percent of non-oil GDP) & -53.8 & -59.5 & -74.2 & -49.7 & -50.0 & -47.7 & -42.2 \\
\hline Non-oil primary fiscal balance (excluding grants) & -20.9 & -25.2 & -30.5 & -27.3 & -26.2 & -25.0 & -22.4 \\
\hline (percent of non-oil GDP) & -50.3 & -56.9 & -70.8 & -45.9 & -46.8 & -45.9 & -40.0 \\
\hline Nominal GDP (billions of U.S. dollars) & 45.2 & 84.9 & 84.9 & 70.6 & 81.2 & 81.2 & 95.2 \\
\hline
\end{tabular}

Sources: Angolan authorities, and IMF staff estimates and projections.

${ }^{1}$ The 2009 etimate for non-bank financing reflects the government's inability to rollover treasury bonds. 
Table 3. Angola: Monetary Survey, 2006-11

(Billions of kwanzas; unless otherwise indicated)

\begin{tabular}{|c|c|c|c|c|c|c|}
\hline & $\begin{array}{l}2006 \\
\text { Dec. }\end{array}$ & $\begin{array}{l}2007 \\
\text { Dec. }\end{array}$ & $\begin{array}{l}2008 \\
\text { Dec. }\end{array}$ & $\begin{array}{l}2009 \\
\text { Dec. }\end{array}$ & $\begin{array}{l}2010 \\
\text { Dec. } \\
\text { Proj. }\end{array}$ & $\begin{array}{l}2011 \\
\text { Dec. } \\
\text { Proj. }\end{array}$ \\
\hline Net foreign assets & 927.4 & $1,030.3$ & $1,481.2$ & $1,130.2$ & $1,665.8$ & $1,815.8$ \\
\hline Net international reserves (BNA) & 689.3 & 849.6 & $1,315.4$ & $1,129.6$ & $1,545.3$ & $1,682.6$ \\
\hline Other foreign assets & -1.4 & -1.3 & -1.3 & -1.6 & -1.7 & -1.7 \\
\hline Commercial banks & 239.5 & 182.1 & 167.1 & 2.1 & 122.2 & 134.9 \\
\hline Net domestic assets & -239.2 & -1.6 & 509.1 & $1,407.8$ & $1,550.8$ & $1,730.3$ \\
\hline Net domestic credit & -210.7 & 96.0 & 594.3 & $1,727.2$ & $1,895.5$ & $2,098.0$ \\
\hline Credit to government (net) & -499.9 & -418.2 & -263.2 & 395.7 & 268.3 & 131.5 \\
\hline Credit to the private sector & 289.2 & 514.2 & 857.6 & $1,331.6$ & $1,627.2$ & $1,966.5$ \\
\hline Counterpart to government deposits abroad & 0.0 & 0.0 & 0.0 & 0.0 & 0.0 & 0.0 \\
\hline Other items (net) & -28.5 & -97.6 & -85.2 & -319.4 & -344.6 & -367.7 \\
\hline M3 & 688.2 & $1,028.7$ & $1,990.3$ & $2,538.0$ & $3,216.7$ & $3,546.1$ \\
\hline Money and quasi money (M2) & 615.6 & 855.1 & $1,417.1$ & $2,303.8$ & $2,785.6$ & $3,355.2$ \\
\hline Money & 474.1 & 711.2 & $1,234.7$ & $1,635.3$ & $2,054.3$ & $2,494.6$ \\
\hline Currency outside banks & 71.6 & 87.5 & 126.1 & 169.7 & 206.3 & 242.7 \\
\hline Demand deposits & 402.5 & 623.7 & $1,108.7$ & $1,465.6$ & $1,847.9$ & $2,251.9$ \\
\hline Quasi-money & 141.5 & 143.9 & 182.4 & 668.5 & 731.3 & 860.6 \\
\hline Repurchase agreements & 72.6 & 173.7 & 573.1 & 234.2 & 431.1 & 190.8 \\
\hline \multicolumn{7}{|l|}{ Memorandum items: } \\
\hline 12-month growth rate of $\mathrm{M} 2$ (percent) & 57.3 & 38.9 & 65.7 & 62.6 & 20.9 & 20.4 \\
\hline Annual inflation (eop) & 12.2 & 11.8 & 13.2 & 14.0 & 13.0 & 9.5 \\
\hline Credit to the private sector (12-month percentage char & 93.1 & 77.8 & 66.8 & 55.3 & 22.2 & 20.9 \\
\hline Total government deposits (in millions of U.S. dollars) & $4,085.7$ & $8,560.2$ & $14,611.8$ & $6,612.5$ & $7,607.0$ & $7,814.2$ \\
\hline Reserve money (billions of kwanzas) & 264.8 & 462.5 & 495.5 & 849.9 & $1,172.2$ & $1,162.1$ \\
\hline Money multiplier & 4.0 & 3.5 & 3.5 & 3.3 & 3.2 & 3.2 \\
\hline
\end{tabular}

Sources: National Bank of Angola (BNA) and IMF staff estimates and projections. 
Table 4. Angola: Monetary Authorities, 2006-11

(Billions of kwanzas; unless otherwise indicated)

\begin{tabular}{|c|c|c|c|c|c|c|}
\hline & $\begin{array}{l}2006 \\
\text { Dec. }\end{array}$ & $\begin{array}{l}2007 \\
\text { Dec. }\end{array}$ & $\begin{array}{l}2008 \\
\text { Dec. }\end{array}$ & $\begin{array}{l}2009 \\
\text { Dec. }\end{array}$ & $\begin{array}{l}2010 \\
\text { Dec. } \\
\text { Proj. }\end{array}$ & $\begin{array}{l}2011 \\
\text { Dec. } \\
\text { Proj. }\end{array}$ \\
\hline Net foreign assets & 687.8 & 848.2 & $1,314.1$ & $1,128.0$ & $1,543.6$ & $1,680.9$ \\
\hline Net international reserves & 689.3 & 849.6 & $1,315.4$ & $1,129.6$ & $1,545.3$ & $1,682.6$ \\
\hline Other foreign assets (net) & -1.4 & -1.3 & -1.3 & -1.6 & -1.7 & -1.7 \\
\hline Net domestic assets & -423.0 & -385.7 & -818.5 & -278.2 & -371.4 & -518.7 \\
\hline Domestic credit & -455.0 & -426.7 & -931.9 & -207.3 & -296.5 & -446.3 \\
\hline Net credit to the government & -457.8 & -456.6 & -935.1 & -294.2 & -299.9 & -450.0 \\
\hline Credit to the private sector & 2.9 & 13.5 & 3.2 & 2.3 & 3.4 & 3.7 \\
\hline Counterpart to government deposits abroad & 0.0 & 0.0 & 0.0 & 0.0 & 0.0 & 0.0 \\
\hline Other assets (net) & 31.9 & 41.0 & 113.4 & -70.8 & -75.0 & -72.4 \\
\hline Reserve money & 264.8 & 462.5 & 495.5 & 849.9 & $1,172.2$ & $1,162.1$ \\
\hline Money base & 153.8 & 247.8 & 400.0 & 702.1 & 877.5 & $1,060.3$ \\
\hline Currency in circulation & 93.8 & 114.8 & 168.4 & 213.9 & 260.0 & 305.9 \\
\hline Deposits of financial insitutions & 60.1 & 133.1 & 231.6 & 488.2 & 617.5 & 754.4 \\
\hline Other deposits & 1.2 & 2.2 & 1.8 & 1.9 & 2.2 & 2.4 \\
\hline BNA bills held by commercial banks & 109.8 & 212.5 & 93.8 & 145.8 & 292.5 & 99.4 \\
\hline \multicolumn{7}{|l|}{ Memorandum items: } \\
\hline Official exchange rate (kwanzas per U.S. dollar; end of period) & 80.2 & 75.0 & 75.1 & 88.3 & $\ldots$ & $\cdots$ \\
\hline 12-month inflation & 12.2 & 11.8 & 13.2 & 14.0 & 13.0 & 9.5 \\
\hline 12-month growth rate of currency in circulation & 19.4 & 22.4 & 46.7 & 27.1 & 21.5 & 17.6 \\
\hline 12-month growth rate of base money & 1.1 & 61.1 & 61.4 & 75.5 & 25.0 & 20.8 \\
\hline Currency velocity (non-oil GDP/average currency) & 17.5 & 19.3 & 19.4 & 17.7 & 17.4 & 17.6 \\
\hline Base money in real terms (12-month growth ) & -9.9 & 44.1 & 42.6 & 54.0 & 10.6 & 10.4 \\
\hline
\end{tabular}

Sources: National Bank of Angola (BNA) and IMF staff estimates and projections. 
Table 5. Angola: Balance of Payments, 2006-11

(Millions of U.S. dollars)

\begin{tabular}{|c|c|c|c|c|c|c|}
\hline & \multirow[t]{2}{*}{2006} & \multirow[t]{2}{*}{2007} & \multirow[t]{2}{*}{2008} & \multirow{2}{*}{$\begin{array}{c}2009 \\
\text { Proj. }\end{array}$} & \multirow{2}{*}{$\begin{array}{l}2010 \\
\text { Proj. }\end{array}$} & \multirow{2}{*}{$\frac{2011}{\text { Proj. }}$} \\
\hline & & & & & & \\
\hline Current account & 11,382 & 9,403 & 6,408 & $-3,703$ & 2,274 & 2,054 \\
\hline Trade balance & 23,084 & 30,735 & 42,932 & 16,195 & 29,922 & 34,828 \\
\hline Exports, f.o.b. & 31,862 & 44,396 & 63,914 & 38,597 & 50,957 & 57,435 \\
\hline Crude oil & 29,929 & 42,352 & 61,666 & 36,675 & 48,749 & 53,956 \\
\hline Refined oil products and gas & 554 & 652 & 792 & 315 & 381 & 414 \\
\hline Diamonds & 1,155 & 1,182 & 1,210 & 1,317 & 1,467 & 2,620 \\
\hline Other & 225 & 211 & 246 & 290 & 359 & 445 \\
\hline Imports, f.o.b. & $-8,778$ & $-13,661$ & $-20,982$ & $-22,402$ & $-21,035$ & $-22,607$ \\
\hline Oil sector & $-2,676$ & $-4,508$ & $-5,713$ & $-5,511$ & $-6,402$ & $-7,200$ \\
\hline Non-oil sector & $-6,102$ & $-9,153$ & $-15,269$ & $-16,891$ & $-14,633$ & $-15,407$ \\
\hline Services (net) & $-6,027$ & $-12,332$ & $-21,810$ & $-11,725$ & $-17,227$ & $-22,120$ \\
\hline Receipts & 1,484 & 311 & 330 & 303 & 402 & 529 \\
\hline Payments & $-7,511$ & $-12,643$ & $-22,139$ & $-12,028$ & $-17,629$ & $-22,649$ \\
\hline Income (net) & $-5,485$ & $-8,778$ & $-14,504$ & $-7,907$ & $-10,222$ & $-10,432$ \\
\hline Receipts & 145 & 33 & 422 & 45 & 54 & 65 \\
\hline Payments & $-5,630$ & $-8,811$ & $-14,926$ & $-7,952$ & $-10,276$ & $-10,497$ \\
\hline Current transfers (net) & -190 & -222 & -210 & -266 & -200 & -222 \\
\hline Financial and capital account & $-3,715$ & $-6,277$ & -725 & $-1,556$ & 1,281 & $-1,055$ \\
\hline Capital transfers (net) & 1 & 7 & 12 & 0 & 0 & 0 \\
\hline Direct investment (net) $1 /$ & -228 & $-1,805$ & -891 & 1,283 & 778 & 675 \\
\hline Medium- and long-term loans & $-1,154$ & 2,524 & 3,834 & 753 & 1,354 & -809 \\
\hline Disbursements & 1,206 & 6,109 & 5,277 & 4,294 & 4,722 & 3,318 \\
\hline Amortization & $-2,360$ & $-3,585$ & $-1,443$ & $-3,541$ & $-3,368$ & $-4,127$ \\
\hline Other capital (net, incl. errors and omissions) & $-2,334$ & $-7,003$ & $-3,679$ & $-3,592$ & -850 & -920 \\
\hline Of which: errors and omissions & 267 & -462 & 366 & $\ldots$ & $\ldots$ & $\ldots$ \\
\hline Overall balance & 6,975 & 3,126 & 5,684 & $-5,259$ & 3,555 & 999 \\
\hline Net international reserves (- increase) & $-5,402$ & $-3,019$ & $-6,673$ & 4,713 & $-3,865$ & $-1,466$ \\
\hline Exceptional financing & $-1,573$ & -107 & 989 & 546 & -400 & 0 \\
\hline Financing gap & 0.0 & -0.2 & 0.4 & 0.0 & 710.0 & 466.3 \\
\hline \multicolumn{7}{|l|}{ Memorandum items: } \\
\hline Current account & 25.2 & 15.9 & 7.6 & -5.2 & 2.7 & 2.2 \\
\hline Trade account & 51.1 & 51.9 & 51.0 & 22.9 & 35.9 & 36.6 \\
\hline Exports of goods and services & 73.8 & 75.4 & 76.3 & 55.1 & 61.6 & 60.9 \\
\hline Imports of goods and services & 36.1 & 44.4 & 51.2 & 48.8 & 46.4 & 47.5 \\
\hline External debt (billions of dollars) & 10.2 & 7.4 & 9.6 & 14.9 & 18.5 & 21.5 \\
\hline External debt & 22.7 & 12.5 & 11.4 & 21.1 & 22.2 & 22.6 \\
\hline NPV of external debt to net exports (percent) & 37.1 & 21.4 & 32.2 & 62.2 & 51.3 & 46.6 \\
\hline Debt-service ratio (percent of exports of goods \& services) & 8.7 & 9.5 & 4.3 & 14.4 & 9.4 & 10.0 \\
\hline Usable reserves (millions of US\$; end of period) & 7,318 & 9,630 & 15,378 & 10,251 & 13,811 & 15,720 \\
\hline Months of imports of goods and services $2 /$ & 3.3 & 2.7 & 5.4 & 3.2 & 3.7 & 4.2 \\
\hline As a ratio of short-term liabilities & 1.0 & 0.8 & 2.1 & 1.1 & 2.0 & 2.0 \\
\hline
\end{tabular}

Sources: National Bank of Angola; and IMF staff estimates and projections.

${ }^{1}$ The net direct investment is largely affected by cost-recovery outflows by oil companies when oil prices are high.

2 In months of next year's imports. 
Table 6. Angola: Banking System Financial Soundness Indicators 2003-09

(Percent at end of period)

\begin{tabular}{|c|c|c|c|c|c|c|c|}
\hline & 2003 & 2004 & 2005 & 2006 & 2007 & 2008 & 2009 \\
\hline \multicolumn{8}{|l|}{ Capital adequacy } \\
\hline Regulatory capital to risk-weighted assets & 18.1 & 19.6 & 19.4 & 18.5 & 21.9 & 19.5 & 22.4 \\
\hline Capital (net worth) to risk-weighted assets & 11.8 & 13.5 & 16.1 & 15.3 & 15.0 & 16.0 & $\ldots$ \\
\hline \multicolumn{8}{|l|}{ Asset quality } \\
\hline Foreign exchange loans to total loans & 27.8 & 55.7 & 72.7 & 71.4 & 69.9 & 61.9 & 65.3 \\
\hline Nonperforming loans to gross loans & 9.0 & 8.1 & 6.4 & 4.8 & 2.9 & 2.4 & 2.6 \\
\hline Provision as percent of capital (net worth) & 13.0 & 13.6 & 9.2 & 8.8 & 4.9 & $\ldots$ & $\ldots$ \\
\hline \multicolumn{8}{|l|}{ Sectoral distribution of credits } \\
\hline Credit to public sector to total credit & 7.7 & 5.2 & 10.0 & 7.1 & 8.1 & 10.1 & 9.4 \\
\hline Credit to private sector to total credit & 92.3 & 94.7 & 89.1 & 92.6 & 91.9 & 89.9 & 90.6 \\
\hline \multicolumn{8}{|l|}{ Net profit } \\
\hline Return on assets (ROA) & 4.7 & 4.1 & 3.1 & 2.7 & 2.7 & 2.4 & 3.4 \\
\hline Return on equity (ROE) & 27.0 & 24.3 & 34.2 & 28.8 & 23.6 & 26.5 & 36.5 \\
\hline Expense/income & 82.2 & 87.7 & 62.5 & 64.5 & 73.6 & $\ldots$ & $\ldots$ \\
\hline \multicolumn{8}{|l|}{ Interest rate spread (deposit money banks) } \\
\hline Lending rate minus demand deposit rates & 71.1 & 62.6 & 32.3 & 18.9 & 9.4 & 9.0 & 9.0 \\
\hline Saving deposit rates & 47.1 & 46.0 & 2.4 & 3.2 & 8.2 & 8.6 & 8.6 \\
\hline Interest margin to gross income & 103.8 & 116.3 & 58.6 & 47.4 & 56.1 & 56.9 & 26.7 \\
\hline \multicolumn{8}{|l|}{ Liquidity } \\
\hline Liquid assets/total assets & 97.0 & 63.9 & 47.1 & 34.4 & 34.2 & 42.6 & 31.4 \\
\hline Liquid assets/short term liabilities & 85.3 & 78.5 & 84.1 & 59.8 & 63.1 & 93.1 & 56.9 \\
\hline Loan/deposits & 38.7 & 45.8 & 39.9 & 45.4 & 54.0 & 53.7 & 55.8 \\
\hline Foreign exchange liabilities/total liabilities & 46.5 & 45.0 & 55.1 & 59.2 & 54.8 & 48.0 & 54.9 \\
\hline \multicolumn{8}{|l|}{ Sensitivity to market risk } \\
\hline Net open position in foreign exchange to capital & 41.6 & 64.1 & 53.1 & 74.34 & 33.0 & 45.5 & 88.8 \\
\hline
\end{tabular}

Source: BNA's Banking Supervision Directorate, and IMF staff estimates. 
Table 7. Angola: External Financing Requirements and Sources, 2009-11 (Millions of U.S. dollars)

\begin{tabular}{|c|c|c|c|}
\hline & 2009 & 2010 & 2011 \\
\hline Gross financing requirements & 5577 & 6210 & 4459 \\
\hline External current acount deficit ${ }^{1}$ & 3703 & -2274 & -2054 \\
\hline Amortization of medium-and long-term debt & 3541 & 3368 & 4127 \\
\hline Exceptional financing & -546 & 400 & 0 \\
\hline Gross reserves accumulation (increase $=+$ ) & -4713 & 3865 & 1466 \\
\hline Other net capital outflows ${ }^{2}$ & 3592 & 850 & 920 \\
\hline Available financing & 5577 & 5500 & 3992 \\
\hline Disbursements $^{3}$ & 4294 & 4722 & 3318 \\
\hline Foreign Direct Investment & 1283 & 778 & 675 \\
\hline Financing need & 0 & 710 & 466 \\
\hline \multicolumn{4}{|l|}{ Financing } \\
\hline IMF: Prospective SBA & 778 & 710 & 266 \\
\hline Donor support & & & 200 \\
\hline
\end{tabular}

Sources: Angolan authorities; and IMFstaff projections.

1 The current account is projected to return to small surpluses in 2010 and 2011 , yet as in the past, part of these surpluses is projected to be re-invested abroad by the oil companies.

2 Includes all other net financial flows, and errors and omissions.

3 The net external borrowing in $2010-11$ is related to the public sector. 
Table 8. Angola: Indicators of Capacity to Repay the Fund, 2009-16

(Million of SDRs, unless otherwise indicated)

\begin{tabular}{lrrrrrrrr}
\hline & 2009 & 2010 & 2011 & 2012 & 2013 & 2014 & 2015 & 2016 \\
\hline Disbursements & 229.0 & 458.1 & 171.8 & 0.0 & 0.0 & 0.0 & 0.0 & 0.0 \\
Repayments & 0.0 & 0.0 & 0.0 & 0.0 & 171.8 & 365.0 & 257.7 & 64.4 \\
Charges/interest & 1.2 & 5.6 & 9.9 & 10.8 & 10.4 & 7.5 & 3.1 & 0.6 \\
Stock of outstanding use of Fund resources & 229.0 & 687.1 & 858.9 & 858.9 & 687.1 & 322.1 & 64.4 & 0.0 \\
Memorandum items: & & & & & & & & \\
Debt service (percent) & & & & & & & & \\
$\quad$ Payments to the Fund/Exports & 0.0 & 0.0 & 0.0 & 0.0 & 0.4 & 0.9 & 0.6 & 0.1 \\
$\quad$ Payments to the Fund/Quota & 0.4 & 2.4 & 3.5 & 3.8 & 73.6 & 130.0 & 81.0 & 22.7 \\
$\quad$ Payments to the Fund/GDP & 0.0 & 0.0 & 0.0 & 0.0 & 0.4 & 0.8 & 0.6 & 0.1 \\
$\quad$ Payments to the Fund/Reserves & 0.0 & 0.1 & 0.1 & 0.1 & 1.1 & 1.7 & 1.2 & 0.2 \\
Outstanding use of Fund resources (in percent) & & & & & & & & \\
$\quad$ Outstanding UFR/Exports & 0.9 & 2.1 & 2.3 & 2.2 & 1.7 & 0.8 & 0.1 & 0.0 \\
$\quad$ Outstanding UFR/Quota & 80.0 & 240.0 & 300.0 & 300.0 & 230.0 & 102.5 & 22.5 & 0.0 \\
$\quad$ Outstanding UFR/GDP & 0.5 & 1.3 & 1.4 & 1.3 & 0.9 & 0.4 & 0.1 & 0.0 \\
$\quad$ Outstanding UFR/Reserves & 2.7 & 6.8 & 7.7 & 5.9 & 4.0 & 1.5 & 0.3 & 0.0 \\
\hline
\end{tabular}

Source: IMF staff estimates. 
Table 9. Angola Reviews and Disbursements under the Proposed 27-month Stand-ByArrangement

\begin{tabular}{|c|c|c|c|}
\hline & \multicolumn{2}{|c|}{ Amount of Purchase } & \multirow[b]{2}{*}{ Condition } \\
\hline & $\begin{array}{l}\text { Percent of } \\
\text { quota }\end{array}$ & Million SDRs & \\
\hline November 23, 2009 & 80 & 229.04 & Upon approval of the SBA \\
\hline [May 10, 2010] & 40 & 114.52 & $\begin{array}{l}\text { Upon completion of the } 1 \text { st review and observance of end- } \\
\text { December } 2009 \text { performance criteria }\end{array}$ \\
\hline September 15, 2010 & 80 & 229.04 & $\begin{array}{l}\text { Upon completion of the } 2 \text { nd and the } 3 \text { rd reviews and observance } \\
\text { of end-June } 2010 \text { performance criteria }\end{array}$ \\
\hline December 15, 2010 & 40 & 114.52 & $\begin{array}{l}\text { Upon completion of the 4th review and observance of end- } \\
\text { September } 2010 \text { performance criteria }\end{array}$ \\
\hline June 15, 2011 & 30 & 85.89 & $\begin{array}{l}\text { Upon completion of the } 5 \text { th review and observance of end-March } \\
2011 \text { performance criteria }\end{array}$ \\
\hline December 15, 2011 & 30 & 85.89 & $\begin{array}{l}\text { Upon completion of the 6th review and observance of end- } \\
\text { September } 2011 \text { performance criteria }\end{array}$ \\
\hline Total & 300 & 973.42 & \\
\hline
\end{tabular}


Table 10. Angola: External Debt Sustainability Framework, 2004-2015

(Percent of GDP, unless otherwise indicated)

\begin{tabular}{|c|c|c|c|c|c|c|c|c|c|c|c|c|c|c|c|}
\hline & & & Actual & & & & & & & & & ctions & & & \\
\hline & 2004 & 2005 & 2006 & 2007 & 2008 & & & 2009 & 2010 & 2011 & 2012 & 2013 & 2014 & 2015 & Debt-stabilizing \\
\hline Baseline: External debt & 46.2 & 33.4 & 16.4 & 16.2 & 16.0 & & & 21.1 & 22.2 & 22.6 & 21.4 & 20.0 & 19.2 & 18.1 & $\begin{array}{c}\text { rent account } 6 \mathrm{i} \\
-3.9\end{array}$ \\
\hline Change in external debt & -15.1 & -12.8 & -17.0 & -0.2 & -0.1 & & & 5.0 & 1.1 & 0.4 & -1.2 & -1.4 & -0.8 & -1.1 & \\
\hline Identified external debt-creating flows $(4+8+9)$ & -26.7 & -31.2 & -33.8 & -16.9 & -11.0 & & & 3.5 & -4.9 & -4.5 & -7.1 & -5.5 & -7.3 & -3.8 & \\
\hline Current account deficit, excluding interest payments & -5.5 & -18.6 & -26.4 & -16.9 & -9.1 & & & 2.3 & -4.5 & -3.9 & -4.7 & -3.2 & -3.9 & -0.6 & \\
\hline Deficit in balance of goods and serices & -98.5 & -98.0 & -88.7 & -87.4 & -86.8 & & & -70.2 & -79.8 & -78.0 & -81.0 & -88.3 & -77.0 & -73.8 & \\
\hline Exports & 69.7 & 79.3 & 73.8 & 75.4 & 76.3 & & & 55.1 & 61.6 & 60.9 & 56.2 & 52.4 & 50.6 & 46.8 & \\
\hline Imports & -28.8 & -18.7 & -14.8 & -12.0 & -10.5 & & & -15.1 & -18.2 & -17.1 & -24.8 & -35.9 & -26.4 & -27.0 & \\
\hline Net non-debt creating capital inflows (negative) & -7.1 & 5.0 & 0.5 & 3.0 & 1.1 & & & -1.8 & -0.9 & -0.7 & -2.7 & -2.6 & -3.7 & -3.7 & \\
\hline Automatic debt dynamics 1 & -14.1 & -17.6 & -7.9 & -3.1 & -2.9 & & & 3.0 & 0.6 & 0.1 & 0.4 & 0.3 & 0.3 & 0.5 & \\
\hline Contribution from nominal interest rate & 2.1 & 1.6 & 1.3 & 1.0 & 1.6 & & & 3.2 & 1.6 & 1.7 & 1.6 & 1.5 & 1.4 & 1.3 & \\
\hline Contribution from real GDP growth & -1.4 & -5.6 & -4.7 & -2.4 & -1.5 & & & -0.2 & -1.1 & -1.6 & -1.3 & -1.2 & -1.0 & -0.8 & \\
\hline Contribution from price and exchange rate changes ${ }^{2}$ & -14.8 & -13.6 & -4.5 & -1.7 & -3.0 & & & & & & $\ldots$ & $\ldots$ & $\ldots$ & & \\
\hline Residual, incl. change in gross foreign assets $(2-3)^{3}$ & 11.7 & 18.4 & 16.8 & 16.7 & 10.8 & & & 1.5 & 6.0 & 4.9 & 5.8 & 4.0 & 6.5 & 2.7 & \\
\hline External debt-to-exports ratio (percent) & 66.3 & 42.1 & 22.2 & 21.4 & 21.0 & & & 38.2 & 36.0 & 37.1 & 38.0 & 38.1 & 37.9 & 38.7 & \\
\hline Gross external financing need (billions of U.S. dollars) ${ }^{4}$ & 1.2 & -3.0 & -9.0 & -5.7 & -5.0 & & & 7.2 & 1.1 & 2.1 & 0.9 & 2.1 & 1.1 & 4.8 & \\
\hline percent of GDP & 6.1 & -9.9 & -20.0 & -9.6 & -5.9 & 10-Year & 10-Year & 11.2 & 1.3 & 2.2 & 0.9 & 1.8 & 0.9 & 3.4 & \\
\hline Scenario with key variables at their historical averages ${ }^{5}$ & & & & & & & & & 7.5 & -6.5 & -18.1 & -28.3 & -36.2 & -43.9 & -0.8 \\
\hline & & & & & & Historical & Standard & & & & & & & & \\
\hline Key Macroe conomic Assumptions Underlying Baseline & & & & & & Average & Deviation & & & & & & & & \\
\hline Real GDP growth (percent) & 3.1 & 20.6 & 19.2 & 19.9 & 12.8 & 10.4 & 7.9 & 1.0 & 6.5 & 8.3 & 6.3 & 6.3 & 5.7 & 4.4 & \\
\hline GDP deflator in U.S. dollars (change in percent) & 31.9 & 41.9 & 15.5 & 11.3 & 22.4 & 25.6 & 25.0 & -24.1 & 18.1 & 8.6 & 3.6 & 7.9 & 2.7 & $\begin{array}{l}5.4 \\
5.3\end{array}$ & \\
\hline Nominal external interest rate (percent) & 4.7 & 6.1 & 5.4 & 8.5 & 13.5 & 6.3 & 2.9 & 15.2 & 9.8 & 8.9 & 8.0 & 7.9 & 7.5 & 7.2 & \\
\hline Growth of exports (U.S. dollar terms, percent) & 42.1 & 76.0 & 37.3 & 34.1 & 43.7 & 35.5 & 24.9 & -39.4 & 32.0 & 12.9 & 3.0 & 5.5 & 4.7 & 1.8 & \\
\hline Growth of imports (U.S. dollar terms, percent) & 21.0 & 0.6 & 16.7 & 5.7 & 24.3 & 11.7 & 12.0 & 20.8 & 42.4 & 7.6 & 61.5 & 63.9 & -20.2 & 12.3 & \\
\hline Current account balance, excluding interest payments & 5.5 & 18.6 & 26.4 & 16.9 & 9.1 & 6.2 & 13.9 & -2.3 & 4.5 & 3.9 & 4.7 & 3.2 & 3.9 & 0.6 & \\
\hline Net non-debt creating capital inflows & 7.1 & -5.0 & -0.5 & -3.0 & -1.1 & 11.1 & 14.8 & 1.8 & 0.9 & 0.7 & 2.7 & 2.6 & 3.7 & 3.7 & \\
\hline
\end{tabular}

'Derived as $[r-g-\rho(1+g)+\varepsilon a(1+r) /(1+g+\rho+g \rho)$ times previous period debt stock, with $r=$ nominal effective interest rate on external debt; $\rho=$ change in domestic GDP deflator in US dollar terms, $g=$ real GDP growth rate,

$\varepsilon=$ nominal appreciation (increase in dollar value of domestic currency), and $\alpha=$ share of domestic-currency denominated debt in total external deb

${ }^{2}$ The contribution from price and exchange rate changes is defined as $[-\rho(1+g)+\infty \alpha(1+r)](1+g+\rho+g \rho)$ times previous period debt stock. $\rho$ increases with an appreciating domestic currency $(\varepsilon>0)$ and rising inflation (based on $G D P$ deflator).

For projection, line includes the impact of price and exchange rate changes,

${ }^{5}$ The

of the last projection yearce that stabilizes the debt ratio assuming that key variables (real GDP growth, nominal interest rate, dollar deffator growth, and non-debt inflows in percent of GDP) remain at their levels 
Table 11. Angola: Public Sector Debt Sustainability Framework, 2004-2015

(Percent of GDP, unless otherwise indicated)

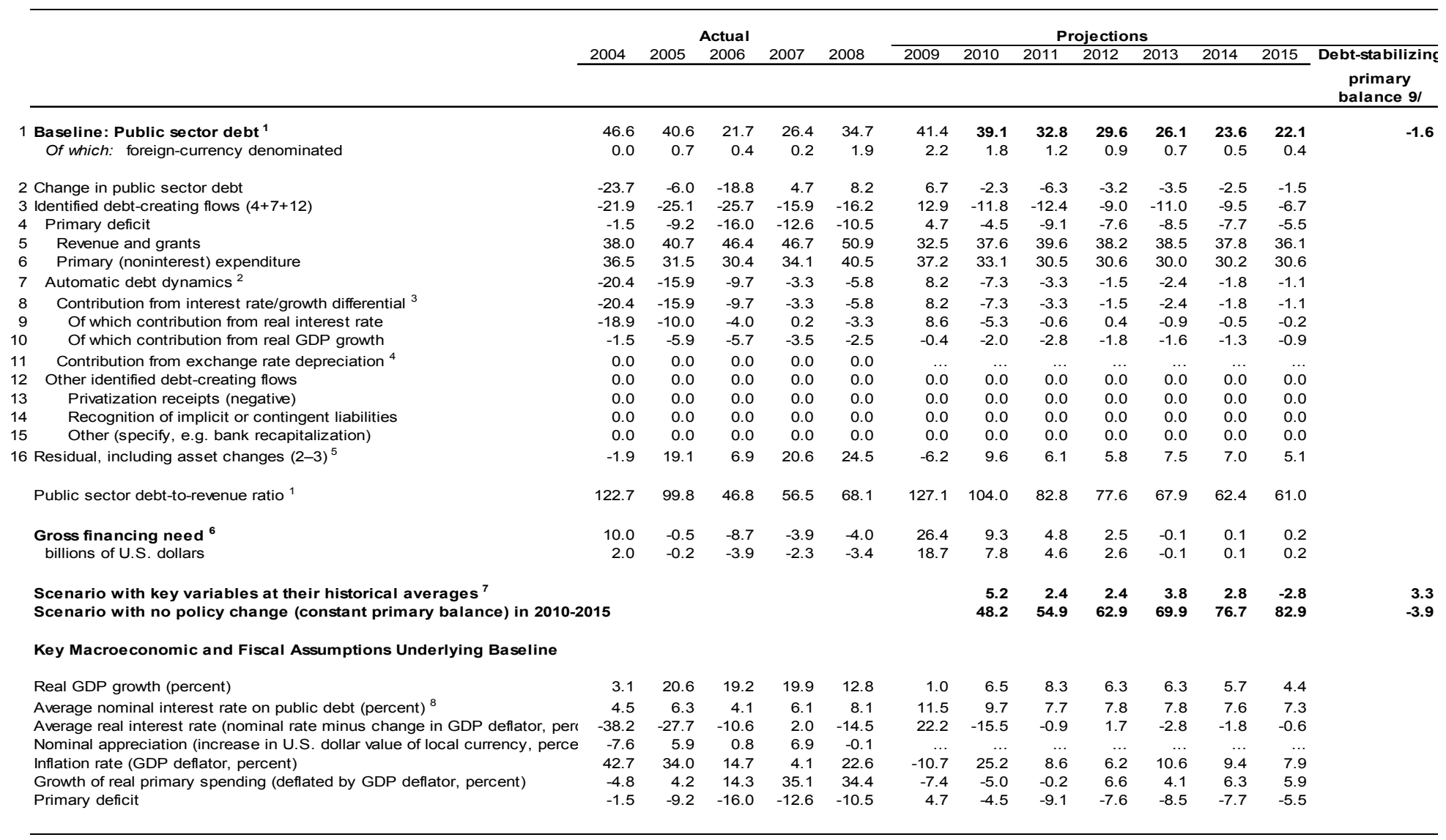

${ }^{1}$ Indicate coverage of public sector, e.g., general government or nonfinancial public sector. Aso whether net or gross debt is used.

${ }^{2}$ Derived as $[(r-\pi(1+g)-g+\alpha z(1+r)](1+g+\pi+g \pi))$ times previous period debt ratio, with $r=$ interest rate; $\pi=$ growth rate of GDP deflator; $g=$ real GDP growth rate; $\alpha=$ share of foreign-currency

denominated debt, and $\varepsilon=$ nominal exchange rate depreciation (measured by increase in local currency value of U.S. dollar).

${ }^{4} \mathrm{~T}$ e real ina

The exchange rate contibution is derived from the numeratorin foono ${ }^{2}$ a $(1+r)$

$6 /$ Defined as public sector deficit, plus amortization of me

end long-term public sector debt, plus short-term debt at end of previous period.

include real GDP growth; real interest rate; and primary balance in percent of GDP.

interest expenditure divided by previous period debt stock.

that key variables (real GDP growth, real interest rate, and other identified debt-creating flows) remain at the level of the last projection year. 
Table 12. Angola: Public Debt, 2003-09

(Billions of U.S. dollars, unless otherwise indicated)

\begin{tabular}{|c|c|c|c|c|c|c|c|}
\hline & 2003 & 2004 & 2005 & 2006 & 2007 & 2008 & $\begin{array}{c}2009 \\
\text { Est. }\end{array}$ \\
\hline Total public debt & 10.3 & 11.5 & 11.7 & 9.4 & 15.2 & 27.6 & 29.2 \\
\hline External debt (excluding late interest) & 10.3 & 10.9 & 10.2 & 7.4 & 9.6 & 13.5 & 15.0 \\
\hline Medium and long-term external debt (excluding late interest) & 8.5 & 9.1 & 10.2 & 7.4 & 9.6 & 13.5 & 14.9 \\
\hline Of which: arrears & 4.3 & 3.0 & 2.6 & 0.8 & 0.4 & 0.3 & 0.3 \\
\hline Domestic debt & 0.4 & 0.6 & 1.4 & 2.0 & 5.6 & 14.1 & 14.1 \\
\hline External Debt by type of creditor & 8.5 & 9.1 & 10.2 & 7.4 & 9.6 & 13.5 & 15.0 \\
\hline Commercial banks & 2.4 & 3.5 & 4.9 & 3.2 & 4.9 & 7.6 & 8.2 \\
\hline Of which: Oil backed loans & 1.8 & 3.4 & 4.8 & 2.9 & 3.9 & 6.0 & 5.3 \\
\hline Arrears & 0.5 & 0.1 & 0.0 & 0.0 & 0.0 & 0.0 & 0.0 \\
\hline Multilateral creditors (IFIs) & 0.3 & 0.4 & 0.4 & 0.4 & 0.4 & 0.4 & 0.7 \\
\hline Of which: arrears & 0.0 & 0.0 & 0.0 & 0.0 & 0.0 & 0.0 & 0.0 \\
\hline Paris Club & 2.5 & 2.5 & 2.4 & 0.6 & 0.3 & 0.3 & 0.2 \\
\hline Of which: arrears & 2.1 & 2.2 & 2.1 & 0.3 & 0.0 & 0.0 & 0.0 \\
\hline Non-Paris Club & 2.2 & 1.8 & 1.9 & 2.6 & 3.6 & 4.7 & 5.1 \\
\hline Of which: arrears & 0.9 & 0.1 & 0.0 & 0.1 & 0.1 & 0.0 & 0.0 \\
\hline Suppliers & 1.1 & 0.9 & 0.7 & 0.6 & 0.4 & 0.6 & 0.8 \\
\hline Of which: arrears & 0.7 & 0.6 & 0.4 & 0.4 & 0.3 & 0.3 & 0.3 \\
\hline Domestic debt by issuer & 0.4 & 0.6 & 1.4 & 2.0 & 5.6 & 14.1 & 14.1 \\
\hline Gov. medium and long-term securities (T-bonds) & 0.4 & 0.6 & 1.4 & 2.0 & 5.6 & 14.1 & 14.1 \\
\hline \multicolumn{8}{|l|}{ Memorandum items } \\
\hline Gross Domestic Product & 14.0 & 19.8 & 30.6 & 45.2 & 59.3 & 84.2 & 70.6 \\
\hline Public debt-to-GDP ratio (percent) & 73.6 & 58.3 & 38.1 & 20.8 & 25.6 & 32.8 & 41.3 \\
\hline External debt-to-GDP ratio (percent) & 61.2 & 46.2 & 33.4 & 16.4 & 16.2 & 16.0 & 21.1 \\
\hline
\end{tabular}

Sources: National Bank of Angola; and IMF staff estimates. 


\section{EXTENDED LETTER OF INTENT}

April $26^{\text {th }}, 2010$

Mr. Dominique Strauss-Kahn

Managing Director

International Monetary Fund

$70019^{\text {th }}$ Street N.W.

Washington, D.C. 20431, USA

Dear Mr. Strauss-Kahn:

1. Angola has benefited greatly from the sound economic policies that the government has pursued, supported by the Stand-By Arrangement with the International Monetary Fund. The resumption of the foreign exchange auction has facilitated a significant and orderly exchange rate adjustment; market conditions have become more settled and we are gradually rebuilding international reserves.

2. The economic outlook for 2010 remains broadly as envisaged since the program was approved. Both the oil and non-oil sectors are on the path of recovery thanks to improved external conditions; inflation is expected to decline further; the external current account and the fiscal balance are projected to return to small surpluses. Overall, the outlook for key macroeconomic variables is in line with the original program, and although some overperformance on reserve accumulation has occurred, we now consider to have a smaller sovereign bond issuance and so our international reserves is likely to be broadly in line with the SBA's goals. It would thus be prudent to wait for signs in the first half of 2010 confirming the continued strengthening of our external position before revising the program targets (with the exception of the external borrowing limit). We will also consider the possibility of converting the current SBA into a precautionary SBA in late 2010.

3. Nevertheless, significant challenges remain to return the economy to a sustainable path, and the government recognizes that there is a need for steadfast implementation of the program. Our main objective continues to be to reduce the non-oil fiscal deficit while providing adequate resources for social spending and vital infrastructure projects. We are also determined to strengthen public financial management and enhance fiscal transparency especially in the oil sector, to further normalize conditions in the foreign exchange market, and to safeguard the financial sector.

4. We are committed to implementing the program described in our original Memorandum of Economic and Financial Policies (MEFP) that was recently approved by the IMF Executive Board. The thrust of our policy agenda remains as described in the MEFP and this extended letter of intent reports on our proposed policies aimed at consolidating on the gains we have already made under the program. To this end, we intend to 
implement the following additional measures aimed at further normalizing the foreign exchange market, strengthening our debt management capacities, improving fiscal transparency, and implementing the recommendations made by the IMF's safeguards assessment.

\section{We acknowledge the important role of a continued tight monetary policy in} supporting the exchange rate policy. In this regard, the following measures will be taken:

- We will revise the reserves requirement regulation to remove the option for arbitrage against the Kwanza. To support this move, BNA is preparing a revision of the norm of reserves requirement. Government securities previously accepted to meet reserve requirements will be removed in the context of the new norm with complementary measures to soften the impact on banks' liquidity. If needed, the treasury will issue competitively priced government paper at the long end of the yield curve to give space to the BNA to use its short-term securities for liquidity management purposes. As part of the policy dialogue between the Angolan Government and the IMF, the revised regulation on reserve requirements will be communicated to Fund staff.

- $\quad$ The treasury and the BNA will regularly discuss the government's financing needs and timing and more generally fiscal and monetary coordination to keep systemic liquidity stable.

- We are planning introduction tighter regulation of the net open position to limit banks exposure to exchange risk and speculation and of a revised regulation on capital requirement on foreign currency loans. The BNA hereby requests further technical assistance from the IMF in the area of liquidity management.

- $\quad$ To improve the functioning of the foreign exchange auction as a market clearing mechanism, in line with our current procedures we will publish on the BNA's web site a circular addressed to auction participants that clarifies the parameters of the auction system. In particular, the BNA will take the following policy actions (i) the only criterion to select bids in the auction is the price proposed by the market makers, starting with the best price offered, while using sales and purchases of foreign exchange to avoid excessive volatility taking into account the program's NIR floor, (ii) the auction will be the only mechanism for purchase and sale of foreign exchange and (iii) the 4 percent limit on the maximum spread above the reference rate for transactions by banks with customers will increased to 6 percent initially with the aim of phasing it out by September 2010. As part of the policy dialogue between the Angolan Government and the IMF, the new circular on the foreign exchange auction will be communicated to Fund staff.

6. Given Angola's immense reconstruction needs and its low debt level, we request greater flexibility in the program's external borrowing ceiling. A large part of the budgeted 
capital spending is associated with external financing. Most is for basic infrastructure that was destroyed during the civil conflict and is vital for development of the country, boosting productivity growth, and removing bottlenecks that have contributed to inflation inertia in Angola. A significant portion of the projects has gone through the appraisal process of the export credit agencies and insurance agencies and the government has its own intensive approval process, which requires scrutiny by the nation's Court of Accounts. The projects contracted with China are subject to a market-based bidding process, while other projects are required to observe OECD rules. In total, the government needs to contract $\$ 6$ billion projectsrelated credit lines in 2010 and a significantly lower amount of contracts are envisaged for future years. Given a disbursement profile spreading over several years, the low beginning debt level, and a favorable growth prospect, external public debtto-GDP ratio will still be on a declining path. While we accept the new debt ceiling of $\$ 6$ billion, we would like to emphasize that this ceiling would need to be kept under constant review given the government's development program, fluctuations in oil prices and the associated changes in the government's external financing needs. As part of regular data reporting, under the program the authorities will now report outstanding stock of undisbursed nonconcessional debt contracted. As noted in our original Letter of Intent (dated November 3, 2009), the government of Angola will consult with the IMF in advance of any revisions following this extended Letter of Intent.

7. Angola is now classified by the IMF as a middle income country. However, our debt management capacity is yet to be at par with those of many other emerging market countries and we acknowledge the urgent need to strengthen our debt management capacity. Improved debt management capacity will strengthen our credibility with international bond investors as we complete our plans for a debt bond issue. These measures will also add credibility to our revised debt ceiling in the SBA program. As a first step, the Cabinet will endorse (by end-September 2010) a package of measures, including (i) developing the capabilities of the debt management unit at the Ministry of Finance,(ii) providing it with clear channels of communication and independent access and reporting lines to the economic ministers, (iii) developing of a clear medium-term debt strategy (with technical assistance from Bank-Fund experts as well as our resident advisor from the U.S. Treasury), and (iv) establishing a project appraisal framework at the Ministry of planning by September 2010. Based on this framework we will submit the first project assessment report by December 2010. As next steps, by end-December 2010, we will initiate substantive reforms regarding the debt management unit and the cabinet will consider and endorse key recommendations of the forthcoming IMF technical assistance on developing a sound medium term debt strategy.

8. We are committed to executing the $\mathbf{2 0 1 0}$ budget in a prudent fashion. We will initiate a revised 2010 budget with the expectation of approving it in July. The revised budget will allocate funds to clear the bulk of the current stock of domestic arrears which amount to about $\$ 4 \frac{1}{2}$ billion and we have entered into negotiations with some of the suppliers to securitize some of the arrears. The revised budget will also aim to phase out the quasi-fiscal operations with Sonangol and gradually reduce fuel subsidies. The revised budget will aim to 
improve the targeting of the public investment program and our new project appraisal framework at the Ministry of Planning will be finalized soon. Part of the spending reduction that would come from the above-mentioned two measures in the revised budget will be reallocated to social spending.

9. The government also attaches paramount emphasis on improving fiscal transparency. We have published Sonangol's 2007 and 2008 audited financial statements, which include its quasi-fiscal operations (prior action). We will also develop an action plan to implement the main recommendations in the audit reports. We are committed to complete and publish the audit of Sonangol's 2009 financial statements, which include its quasi-fiscal operations by November 2010. In addition, we will study the legal and institutional preconditions, in order to assess the feasibility of developing an action plan on implementing the IMF's Principles on Resource Revenue Transparency and will communicate our decision by September 2010.

10. To enhance external oversight and internal controls at the BNA, we are committed to implement in a timely manner the high-priority recommendations that emerge from the recent safeguards assessments exercise to reduce safeguard risks, including: (i) timely publication of the audited financial statements, (ii) implementation of a new governance and control framework over the management of international reserves, and (iii) strengthening the central bank law. As the first step to strengthen data compilation practices, the BNA has reconciled fully international reserves data between accounting and DGR (reserves management department) as of end-December 2009, eliminating the relevant inconsistencies in the accounts.

11. We agree with the IMF's new definition of the usable net international reserves (NIR), which make it operationally easier to track over time, and concur on including these changes in the program definition (see attached Technical Memorandum of Understanding). We hereby confirm that the calculated usable NIR at end-2009 are not in any way encumbered even after taking into account BNA's second tier guarantee of China and Brazil credit lines. In addition, we agree that completion of the 2009 accelerated audit and signing by the BNA is a prior action for the completion of the first review under the SBA. This would be followed by a special audit by end-August of the BNA's NIR position for end-June 2010 as a prior action for completing the second SBA review.

\section{The government recognizes the importance of engaging with the FATF and} indicating a political commitment to address the deficiencies in our AML/CFT framework. To this end, the Council of Ministers has already approved an AML/CFT law, and already submitted it to the National Assembly. Our overarching priorities are to enact AML/CFT legislation in line with international standards, to implement appropriate preventive measures in the financial sector (including a suspicious transactions reporting regime), and to create the necessary institutional framework to support the AML/CFT structure, including a Financial Intelligence Unit (FIU). 
13. Given the success to date of the program and corrective policy measures, we request the granting of waivers and the completion of the first SBA review. For end-March 2010 data that are not yet available, we request waivers for applicability except for the performance criteria related to external and domestic arrears for which we are requesting waivers for nonobservance. Most of the end-December 2009 program targets were observed. The very modest arrears to IDA of $\$ 1.3$ million ( 0.002 percent of GDP) - which arose from an oversight in the debt servicing unit - have been cleared. Regarding domestic arrears, they resulted from the shortfall of projected financing against the backdrop of worsened market conditions. To avoid any future accumulation of arrears, we intend to ensure full financing of the budgeted expenditures. As stated above, we will also craft a clear plan to clear the existing stock of arrears in the forthcoming 2010 revised budget in July/August.

\section{The program will continue to be monitored through quantitative performance} criteria and indicative targets, as well as structural benchmarks and quarterly reviews (see attached Tables 1 and 2). Due to the delay in completing the first review under the SBA, we are requesting a rephasing and thus the second review and third reviews will be combined and take place no later than September 15, 2010.

15. Under the SBA, the government will regularly update the IMF on economic and policy developments and will provide the data needed for adequate monitoring of the program. During the period of the SBA, the government of Angola will maintain close policy dialogue with the IMF, is prepared to take any further measures as appropriate, and will consult with the Fund in advance of revisions to measures already contained in the attached MEFP. In addition, in line with good communication to the public and markets, we authorize the IMF to publish this extended letter of intent and the related staff report.

Sincerely yours,

$$
\text { /s/ }
$$

Manuel Nunes Junior

Minister of State and Economic Coordination

$$
/ \mathrm{s} /
$$

Mr. Carlos Alberto Lopes

Minister of Finance

Attachment: Technical Memorandum of Understanding 
Table 1. Angola: Quantitative Performance Criteria (PC) and Indicative Targets (IT)

December 2009-December 2010

\begin{tabular}{|c|c|c|c|c|c|c|c|}
\hline & \multicolumn{3}{|c|}{ December 2009} & \multirow{2}{*}{$\begin{array}{l}\text { March } 2010 \\
\text { PC }\end{array}$} & \multirow{2}{*}{$\begin{array}{l}\text { June } 2010 \\
\text { PC }\end{array}$} & \multirow{2}{*}{$\begin{array}{l}\text { September } 2010 \\
\text { PC }\end{array}$} & \multirow{2}{*}{$\begin{array}{l}\text { December } 2010 \\
\text { PC }\end{array}$} \\
\hline & $\mathrm{PC}$ & Adjusted PC & Actual & & & & \\
\hline \multicolumn{8}{|l|}{ Performance criteria ${ }^{1}$} \\
\hline Usable net international reserves, floor (millions of US $\$)^{2}$ & 9076 & 8098 & 10251 & 9567 & 10058 & 10549 & 11040 \\
\hline Net domestic credit of the BNA, ceiling (billions of kwanzas) ${ }^{3}$ & -311 & -56 & -207 & -308 & -304 & -300 & -296 \\
\hline $\begin{array}{l}\text { Net credit to the government by the banking system, Ceiling (billions of } \\
\text { kwanzas) }{ }^{4}\end{array}$ & 268 & 523 & 396 & 268 & 268 & 268 & 268 \\
\hline Nonaccumulation of domestic arrears, cumulative (billions of kwanzas) ${ }^{5}$ & 0 & 0 & 116 & 0 & 0 & 0 & 0 \\
\hline Nonaccumulation of external arrears, cumulative (billions of US $\$)^{6}$ & 0 & 0 & 0.00137 & 0 & 0 & 0 & 0 \\
\hline External borrowing, cumulative, ceiling (billions of US\$) & 2 & 0 & 0 & 2 & 6 & 6 & 6 \\
\hline \multicolumn{8}{|l|}{ Indicative target } \\
\hline Floor on social spending, cumulative effective January 1 (billion of kwanza) & 786 & 786 & 600 & 205 & 411 & 616 & 821 \\
\hline $\begin{array}{l}\text { Nonoil fiscal deficit (on accrual basis), cumulative effective January } 1 \text {, } \\
\text { ceiling (billions of kwanzas) }\end{array}$ & 1800 & 1800 & 1551 & 483 & 967 & 1450 & 1934 \\
\hline
\end{tabular}

${ }^{1}$ Evaluated at the programmed exchange rate.

${ }^{2}$ The floor on NIR will be adjusted upward (downward) by the excess (shortfall) of oil revenues received by the Treasury and by the shortfall (excess) of the central government's external debt service relative to program assumptions. The adjustors will be applied only to the extent that the floor on the stock of NIR remains at or above US $\$ 6$ billion.

${ }^{3}$ The ceiling for NDC will be adjusted upward (downard) by the shortfall (excess) in oil revenues received by the Treasury and by the excess (shortfall) of the central government's external debt service relative to program assumptions.

${ }^{4}$ The ceiling for NCG will be adjusted upward (downward) by the shortfall (excess) in oil revenues received by the Treasury and by the excess (shortfall) of the central government's external debt service relative to program assumptions.

${ }^{5}$ Effective November 23, 2009

${ }^{6}$ Continuous performance criterion. 
Table 2. Angola: Proposed Structural Measures in the Program

\begin{tabular}{|c|c|c|}
\hline Objectives & Actions & Timing \\
\hline \multicolumn{3}{|l|}{ Prior actions } \\
\hline Strengthen fiscal transparency & $\begin{array}{l}\text { Publication of Sonangol's } 2007 \text { and } 2008 \text { audited financial statements } \\
\text { which includes its quasifiscal operations }\end{array}$ & April 2010 \\
\hline Strengthen transparency & $\begin{array}{l}\text { Publication of the audited financial statements of BNA for } 2008 \text {, } \\
\text { including the explanatory notes and Deloitte's signed audit opinion, on } \\
\text { the BNA's external website }\end{array}$ & April 2010 \\
\hline Strengthen transparency & $\begin{array}{l}\text { Completion of the audited financial statements of BNA for } 2009 \text {, with } \\
\text { the signing of the BNA }\end{array}$ & April 2010 \\
\hline \multicolumn{3}{|l|}{ Structural benchmarks } \\
\hline Reduce financial sector vulnerability & $\begin{array}{l}\text { Amend provisioning regulation to reflect the credit risk of foreign } \\
\text { currency loans }\end{array}$ & March 2010 \\
\hline Reduce financial sector vulnerability & $\begin{array}{l}\text { Development of an off-site supervisory tools to monitor banks' credit } \\
\text { exposures by currency and maturities }\end{array}$ & March 2010 \\
\hline Limit fiscal risks & Cabinet approval of the tax reform strategy & June 2010 \\
\hline Improve public financial management & $\begin{array}{l}\text { i) Publication of quarterly budget execution reports by the central } \\
\text { government; } \\
\text { ii) Reporting on a quarterly basis by major SOEs to the government of } \\
\text { their quasi-fiscal operations and investment activities and publishing } \\
\text { the reports }\end{array}$ & June 2010 \\
\hline Improve public financial management & Establishment of the project appraisal framework & September 2010 \\
\hline Improve public financial management & Completion of the first project assessment report & December 2010 \\
\hline Improve public financial management & $\begin{array}{l}\text { Submission to the cabinet of the approval documents of the Angola } \\
\text { Sovereign Wealth Fund (future SBA reviews will set benchmarks on } \\
\text { implementation) }\end{array}$ & June 2010 \\
\hline Improve public debt management & $\begin{array}{l}\text { Cabinet approval the main recommendations of the forthcoming IMF } \\
\text { technical assistance on developing a sound medium term debt } \\
\text { strategy }\end{array}$ & December 2010 \\
\hline Strengthen fiscal transparency & $\begin{array}{l}\text { Publication of the audit of Sonangol's } 2009 \text { financial statements which } \\
\text { includes its quasifiscal operations }\end{array}$ & November 2010 \\
\hline
\end{tabular}


Table 2. Angola: Proposed Structural Measures in the Program (continued)

\begin{tabular}{|c|c|c|}
\hline Objectives & Actions & Timing \\
\hline Strengthen transparency & $\begin{array}{l}\text { Publication of the audited financial statements of BNA for } 2009 \text {, } \\
\text { including the explanatory notes and Deloitte's signed audit opinion, on } \\
\text { the BNA's external website }\end{array}$ & June 2010 \\
\hline Mitigate safeguards risks & $\begin{array}{l}\text { Completion of an external audit on BNA by an international audit firm } \\
\text { to confirm: (i) the existence, availability, and fair value of foreign } \\
\text { assets as of June 2010; and (ii) the accuracy of NIR data reported to } \\
\text { the Fund, including compliance with the definitions agreed under the } \\
\text { program. The scope of the audit should be based on Terms of } \\
\text { Reference agreed with Fund staff }\end{array}$ & August 2010 \\
\hline Mitigate safeguards risks & $\begin{array}{l}\text { Appointment of an investment committee by the Board of Directors of } \\
\text { BNA to meet at least monthly to oversee reserves management } \\
\text { operations and reporting }\end{array}$ & May 2010 \\
\hline Mitigate safeguards risks & $\begin{array}{l}\text { Formalization of investment guidelines for foreign reserves of the } \\
\text { BNA by the Board of Directors of BNA }\end{array}$ & July 2010 \\
\hline Mitigate safeguards risks & $\begin{array}{l}\text { Issuance of semiannual reports by the Internal Audit Office of the } \\
\text { BNA to the Board on compliance with the foreign reserve investment } \\
\text { guidelines }\end{array}$ & September 2010 \\
\hline Mitigate safeguards risks & $\begin{array}{l}\text { Appointments of consultants with significant proven experience in } \\
\text { capacity building within the field of internal auditing for a minimum } \\
\text { period of two years to build capacity and bring the Internal Audit } \\
\text { Office of the BNA up to the level of a modern internal audit function }\end{array}$ & June 2010 \\
\hline Strengthen central bank governance & $\begin{array}{l}\text { Reconstituting the Audit Board by (i) replacing the member who has a } \\
\text { conflict of interest, (ii) adopting a Charter to define all statutory } \\
\text { responsibilities, and (iii) assuming oversight of the external audit and } \\
\text { financial reporting process. }\end{array}$ & June 2010 \\
\hline
\end{tabular}




\section{AtTachment}

\section{TEChNiCAL MEMORANDUM OF Understanding (TMU)}

This memorandum sets out the understandings between the Angolan authorities and the IMF staff regarding the definition of performance criteria and indicative targets, their adjustors, and data reporting requirements for the duration of the Stand-By-Arrangement. Where these criteria and targets are numeric, their unadjusted number values are stated in Table 1 of the Letter of Intent and Memorandum of Economic and Financial Policies. The values against which program compliance will be assessed will be adjusted up or down according to the adjustors specified in this Memorandum. ${ }^{1}$

\section{A. Ceiling on the Overall Non-Oil Primary Deficit on Accrual Basis of the Central Government}

\section{Definition}

1. The Central Government will observe a ceiling on its Overall Non-Oil Primary Deficit on an Accrual Basis. The observance of this floor is an indicative target. Overall Non-Oil

Primary Deficit on Accrual Basis of the Central Government is defined as the cumulative balance since the start of the calendar year of its revenues, except oil-related, and expenditures of the Central Government, except interest payments. It is measured on an accrual basis and therefore it does not include accumulation or clearance of arrears.

\section{Adjustors}

The ceiling will be adjusted downward by

- $\quad$ The donor-financed expenditures in excess of the program assumptions.

The ceiling will be adjusted upward by

- $\quad$ The shortfall in donor-financed expenditures relative to program assumptions.

\section{Data Reporting Requirements}

2. Data on the implementation of the budget compiled by the Treasury will be provided on a quarterly basis, to be submitted no later than eight weeks after the end of each reporting period.

\footnotetext{
${ }^{1}$ For program purposes, net international reserves and the adjustors are valued at the end-December 2009 prevailing exchanges rates (the "program exchange rates").
} 
3. The data to be reported are:

- $\quad$ Flows of (i) government revenue by category (including oil revenues received by the treasury); (ii) government expenditure, including primary current expenditure, domestic and external interest payments, and capital expenditure, of all donor-financed expenditures and resulting from agreements with the Paris Club; (iii) the gross clearance and gross accumulation of domestic and external arrears; (iv) external loan receipts and principal payments; (v) bank and nonbank financing, discriminating the domestic assets from liabilities; (vi) debt cancellation and debt swap operations; (vii) any other revenue, expenditure, or financing not included above.

- $\quad$ Stocks of public domestic debt and external debt.

- $\quad$ The monthly debt service projected for the next 12-months and annual debt service for the outer years.

\section{B. Ceiling on the Net Domestic Credit by the Central Bank}

\section{Definition}

4. There will be a ceiling on the Net Domestic Credit by the Central Bank. The observance of this ceiling is a performance criterion. Net Domestic Credit (NDC) by the Central Bank are defined as the cumulative change, from the beginning of calendar-year, of the stocks of reserve money minus net foreign assets and other assets (net), evaluated at endof-period exchange rates. Reserve money comprises bank reserves, cash in circulation, and deposits of the monetary institutions as well as BNA securities outstanding.

\section{Adjustors}

The ceiling for NDC will be adjusted upward by

- $\quad$ The shortfall in oil revenues received by the Treasury relative to program assumptions.

- $\quad$ The external debt service by the central government in excess of program assumptions.

- $\quad$ The shortfall of nonproject medium and long-term central government external borrowing relative to program assumptions.

The ceiling for NDC will be adjusted downward by

- $\quad$ The oil revenues received by the Treasury in excess of the program assumptions.

- The shortfall in external debt service by the central government relative to program assumptions.

- The nonproject medium and long-term central government external borrowing in excess of program assumptions. 


\section{Data Reporting Requirement}

5. The monthly balance sheets of the central bank and the consolidated commercial banks will be transmitted on a monthly basis, with a maximum delay of three weeks.

\section{Ceiling on Net Credit to the Central Government by the Banking System (NCG)}

6. There will be a ceiling on the Net Credit to the Central Government by the Banking System. The observance of this ceiling is a performance criterion. Net credit to the central government from the banking system is defined as the overall position of the main central government institutions vis-à-vis the banking system - that is, the stock of all outstanding claims on the central government (loans, advances and arrears), and all other government debt instruments, such as long-term government securities, held by the BNA and commercial banks less all deposits held by the central government with the BNA and with commercial banks.

\section{Adjustors}

The ceiling for NCG will be adjusted upward by

- $\quad$ The shortfall in oil revenues received by the Treasury relative to program assumptions.

- $\quad$ The external debt service by the central government in excess of program assumptions.

- $\quad$ The shortfall of nonproject medium and long-term central government external borrowing relative to program assumptions.

The ceiling for NCG will be adjusted downward by

- $\quad$ The oil revenues received by the Treasury in excess of the program assumptions.

- The shortfall in external debt service by the central government relative to program assumptions.

- $\quad$ The nonproject medium and long-term central government external borrowing in excess of program assumptions.

For purposes of calculating the adjustors, these flows will be valued at current exchange rates.

\section{Data Reporting Requirement}

7. Data on the implementation of the budget compiled by the Ministry of Finance and Public Administration will be provided on a quarterly basis, to be submitted no later than six weeks after the end of each quarter, including (i) government domestic revenue by category; (ii) external budget support grants; (iii) government expenditure, including primary current expenditure, domestic and external interest payments, and capital expenditure, including domestically and budget support financed capital expenditure and estimates of externally 
project financed capital expenditure; (iv) the gross payment and gross accumulation of domestic accounts payable; (v) the gross payment and gross accumulation of domestic payments arrears; (vi) external loan receipts and principal payments; (vii) external arrears

payments and accumulation; (viii) bank and nonbank financing; (ix) privatization and land sale receipts; and (x) any other revenue, expenditure, or financing not included above.

8. For the purposes of this memorandum, privatization and land proceeds will be understood to mean all monies received by the government from the sale or concessioning of a public company, organization, or facility to a private company or companies, organization(s), or individual(s), as well as any proceeds generated from the sale of government land and the liquidation of a public company, less restructuring costs.

\section{Floor on the Net International Reserves of the Central Bank}

\section{Definition}

9. Net international reserves (NIR) of the National Bank of Angola (BNA) are defined as the dollar value of gross foreign assets of the BNA minus gross foreign liabilities of the BNA with maturity of less than one year and all of Angola's credit outstanding from the Fund. Nondollar denominated foreign assets and liabilities will be converted into dollars at the program exchange rates. Data will be provided by the BNA to the Fund with a lag of not more than 1 week past the test date.

- $\quad$ Gross foreign assets are defined as readily available claims on nonresidents denominated in foreign convertible currencies. They include the BNA's holdings of monetary gold, SDRs, foreign currency cash, foreign currency securities, deposits abroad, and the country's reserve position at the Fund. Excluded from reserve assets are any assets that are pledged, collateralized, or otherwise encumbered, claims on residents, claims in foreign exchange arising from derivatives in foreign currencies vis-à-vis domestic currency (such as futures, forwards, swaps, and options), precious metals other than gold, assets in nonconvertible currencies, and illiquid assets. As of December 31, 2009, foreign reserve assets thus defined amounted to US\$ 10.888 billion.

- Gross foreign liabilities are defined as all short-term foreign exchange liabilities of the BNA to nonresidents, including commitments to sell foreign exchange arising from derivatives (such as futures, forwards, swaps, and options) and all credit outstanding from the Fund. As of December 31, 2009, reserve liabilities thus defined amounted to US\$ 0.365 million.

\section{Adjustors}

The floor on NIR will be adjusted upward by

- The oil revenues received by the Treasury in excess of the program assumptions. 
- The shortfall in external debt service by the central government relative to program assumptions.

- $\quad$ The nonproject medium and long-term central government external borrowing in excess of program assumptions.

The floor on NIR will be adjusted downward by

- $\quad$ The shortfall in oil revenues by the Treasury relative to program assumptions.

- $\quad$ The external debt service by the central government in excess of program assumptions.

- $\quad$ The shortfall of nonproject medium and long-term central government external borrowing relative to program assumptions.

The adjustors will be applied only to the extent that the floor on the stock of NIR remains at or above US\$6 billion.

\section{Data Reporting Requirement}

10. A table prepared by the central bank will be transmitted weekly, with a maximum delay of one week, with the daily values of the stock of NIR and the decomposition of the daily variation of the NIR stock into foreign exchange sales to, and purchases from, the government, banks, nonbanks, and SDR purchases from the IMF, interest accrual, and valuation changes. The table will also indicate any off-balance sheet position denominated or payable in foreign currency by the central bank. Data on exports and imports, including volume and prices and compiled by the Customs and central bank will be transmitted on a quarterly basis within six weeks after the end of each quarter. A preliminary quarterly balance of payments (including nonproject medium and long-term central government external borrowing), compiled by the central bank, will be forwarded within six weeks after the end of each quarter.

\section{E. Ceiling on External Debt Contracted or Guaranteed by the Central Government}

\section{Definition $^{2}$}

11. The definition of debt for program purposes is set out in Executive Board Decision No. 12274, Point 9, as revised on August 31, 2009 (Decision No. 14416-(09/91)) (see Annex I).

\footnotetext{
${ }^{2}$ Given that Sonangol is independent from the government and operates as a commercial entity and due to the fact that it borrows without a government's guarantee, it is excluded from the ceiling on the non-concessional borrowing. Other SOEs are also excluded due to their low weight in the public sector and the fact that they do not pose substantial fiscal risks.
} 
12. There will be a ceiling on debt contracted or guaranteed by the central government and the BNA with non residents effective from the date of Board approval of the arrangement. The ceiling is specified in Table 1. The ceiling applies to debt and commitments contracted or guaranteed for which value has not yet been received. This applies to private debt for which official guarantees have been extended and which, therefore, constitute a contingent liability of the public sector. The observance of this ceiling is a performance criterion. Sonangol and other SOEs will not contract debt on behalf of the central government. For program purposes, all debt that are in currencies other the U.S. dollar will be converted into U.S. dollars at program exchanges.

13. Excluded from the ceiling are (i) the use of fund resources (ii) debts incurred to restructure, refinance, or prepay existing debt. These are further specified in Table 1 of the Memorandum of Economic and Financial Policies.

14. For program purposes, the guarantee of a debt arises from any explicit legal obligation of the public sector to service a loan in the event of nonpayment by the recipient (involving payments in cash or in kind), or indirectly through any other obligation of the public sector to finance partially or in full any shortfall incurred by the loan recipient.

\section{Data reporting requirements}

15. The government will consult with Fund staff before assuming any liabilities in circumstances where they are uncertain whether the instrument in question falls under the performance criterion. A debt-by-debt accounting of all new debt contracted or guaranteed by the central government, including the original debt documentation, details on debt service obligations, as well as all relevant supporting materials, will be transmitted within six weeks of the end of each quarter. The data on outstanding stock of undisbursed nonconcessional debt as well as outstanding stock of unused credit lines from framework agreements will be reported to Fund staff at the end of each quarter. In addition, during the preparation of the budget, the full breakdown of projected disbursements for the budget from old project debt contracts and new project debt contracts will be provided to Fund staff.

\section{F. Nonaccumulation of Domestic Payments Arrears}

\section{Definition}

16. The central Government may not accumulate additional domestic payments arrears. This obligation is a performance criterion. A domestic payment obligation is deemed to be in arrears if it has not been paid within the due date either specified by the budget law or contractually agreed with the creditor. After rescheduling by agreement with the creditor, the obligation rescheduled is not considered in arrears anymore. 


\section{Data Reporting Requirement}

17. The Treasury will submit on a quarterly basis a detailed table of the stock of domestic payments arrears, including the accumulation, clearance, rescheduling and write-off of domestic payments arrears during the quarter. The data are to be provided within six weeks after the end of the quarter.

\section{G. Nonaccumulation of External Payments Arrears}

\section{Definition}

18. The central Government may not accumulate external payments arrears. This obligation is a performance criterion. External arrears are defined as total external debtservice obligations of the government and the central bank that have not been paid by the time they are due, except where agreements between the government and creditors explicitly provide for a grace period after such obligations falling due, in which case the obligation will be in arrears if not paid within the grace period. Obligations in negotiation with creditors are considered arrears until an agreement is legally in effect.

\section{Data Reporting Requirements}

19. Data on external arrears accumulation, clearance, and rescheduling will be transmitted weekly by the BNA at most one week after the fact.

\section{H. Floor on the Central Government Social Expenditures}

\section{Definition}

20. There will be a floor on the Central Government Social Expenditures. The observance of this floor is an indicative target. Social Spending comprises spending on the following sectors: education, health, rural development, and social affairs, both spending for the current year and arrears repayment related to these sectors.

\section{Data Reporting Requirements}

21. Data on Social Spending will be compiled by the Treasury and will be provided on a quarterly basis, to be submitted no later than six weeks after the end of each reporting period. 


\section{Guidelines on Performance Criteria With Respect to Foreign DebT}

Excerpt from Executive Board Decision No. 12274, as revised on August 31, 2009 (Decision No. 14416-(09/91)).

9. (a) For the purpose of this guideline, the term "debt" will be understood to mean a current, i.e., not contingent, liability, created under a contractual arrangement through the provision of value in the form of assets (including currency) or services, and which requires the obligor to make one or more payments in the form of assets (including currency) or services, at some future point(s) in time; these payments will discharge the principal and/or interest liabilities incurred under the contract. Debts can take a number of forms, the primary ones being as follows:

(i) loans, i.e., advances of money to the obligor by the lender made on the basis of an undertaking that the obligor will repay the funds in the future (including deposits, bonds, debentures, commercial loans and buyers' credits) and temporary exchanges of assets that are equivalent to fully collateralized loans under which the obligor is required to repay the funds, and usually pay interest, by repurchasing the collateral from the buyer in the future (such as repurchase agreements and official swap arrangements);

(ii) suppliers' credits, i.e., contracts where the supplier permits the obligor to defer payments until some time after the date on which the goods are delivered or services are provided; and

(iii) leases, i.e., arrangements under which property is provided which the lessee has the right to use for one or more specified period(s) of time that are usually shorter than the total expected service life of the property, while the lessor retains the title to the property. For the purpose of the guideline, the debt is the present value (at the inception of the lease) of all lease payments expected to be made during the period of the agreement excluding those payments that cover the operation, repair or maintenance of the property.

(b) Under the definition of debt set out in point 9 (a) above, arrears, penalties, and judicially awarded damages arising from the failure to make payment under a contractual obligation that constitutes debt are debt. Failure to make payment on an obligation that is not considered debt under this definition (e.g., payment on delivery) will not give rise to debt. 


\section{ANNEX I-ANGOla: RELATIONS WITH THE FUND}

(As of March 31, 2010)

I. Membership Status: Joined September 19, 1989; Article XIV

II. General Resources Account:

Quota

Fund holdings of currency

III. SDR Department:

Net cumulative allocation

Holdings

IV. Outstanding Purchases and Loans:

Stand-By Arrangements
SDR Million

286.30

515.49

SDR Million

273.01

271.03

SDR Million

229.04
Percent

100.00

180.05

Percent

100.00

99.27

Percent

80.00

V. Latest Financial Arrangements:

$\begin{array}{ccccc}\text { Type } & \begin{array}{c}\text { Date of } \\ \text { Arrangement }\end{array} & \begin{array}{c}\text { Expiration } \\ \text { Date }\end{array} & \begin{array}{c}\text { Amount Approved } \\ \text { (SDR Million) }\end{array} & \begin{array}{c}\begin{array}{c}\text { Amount Drawn } \\ \text { (SDR Million) }\end{array} \\ \text { Stand-By }\end{array} \\ \text { Nov 23, 2009 } & \text { Feb 22, 2012 } & 858.90 & 229.04\end{array}$

VI. Projected Payments to Fund: (SDR Million)

\begin{tabular}{lrrrrr} 
& \multicolumn{5}{c}{ Forthcoming } \\
\cline { 2 - 6 } & 2010 & 2011 & 2012 & 2013 & 2013 \\
\cline { 2 - 6 } Principal & & & & 114.52 & 114.52 \\
Charges/Interest & 2.17 & 2.89 & 2.89 & 2.43 & 1.03 \\
Total & 2.17 & 2.89 & 2.89 & 116.95 & 115.55
\end{tabular}

\section{Implementation of HIPC Initiative: Not applicable}

VIII. Safeguards Assessments: The first-time safeguards assessment of the National Bank of Angola (BNA) found that the central bank is subject to annual external audits by a reputable audit firm and has taken steps to address the audit qualifications. The assessment confirmed, however, weak governance and transparency practices at the BNA, including lack of timely publication of annual financial statements. The assessment also made recommendations to enhance the legal framework and independence of the central bank, and to strengthen the control framework in the reserves management and internal audit areas.

IX. Exchange Arrangements: Angola's de facto exchange arrangement has been classified as "other managed" since October 2009. The Banco Nacional de Angola (BNA) intervenes actively in the foreign exchange market in order to sterilize foreign currency inflows in the form of taxes paid by oil companies. Auctions were temporarily suspended from April 20 to October 1, 2009 leading to the establishment of a formal peg.

Since the resumption of auctions, the Kwanza has depreciated significantly. However, the authorities maintain strong control on the exchange rate, which is the main anchor for the 
monetary policy. The BNA publishes a daily reference rate, which is computed as the transaction-weighted average of the previous day's rates negotiated with commercial banks. Banks and exchange bureaus may deal among themselves and with their customers at freely negotiated rates.

Angola continues to avail itself of the transitional arrangements under the provisions of Article XIV, Section 2 and maintains two exchange measures, namely, (i) limits on the availability of foreign exchange for invisible transactions, such as travel, medical, or educational allowances and (ii) limits on unrequited transfers to foreign-based individuals and institutions. In addition, Angola maintains two exchange restrictions resulting from: (i) limits on the remittances of dividends and profits from foreign investments that do not exceed US $\$ 100,000$ and (ii) the discriminatory application of the 0.015 percent stamp tax on foreign exchange operations that are subject to approval under Article VIII, Section 2(a). Furthermore, Angola maintains two multiple currency practices (i) arising from the Dutch foreign exchange auction and (ii) the discriminatory application of the 0.015 stamp tax on foreign exchange operations that are subject to approval under Article VIII, Section 3.

X. Article IV Consultation: Angola is on the standard 12-month cycle.

XI. Technical Assistance: Angola has received substantial technical assistance since it joined the Fund in 1989. The following summarizes technical assistance since 1999:

\section{Monetary and Capital Markets (MCM)}

Banking supervision, resident medium-term advisors

Monetary policy, short-term visits

Foreign exchange operations

Central bank organization

Inspection/technical assistance assessment

Monetary operations

Open market and interbank operations

Foreign exchange operations

Monetary operations/TA assessment

Monetary policy and foreign exchange market operations

Monetary policy, money market operations,

and banking supervision

Strengthening monetary and supervisory frameworks

and reinforcing the disinflation strategy

Monetary operations and liquidity management,

foreign exchange operations, and banking supervision

Foreign exchange auction system
Year of Delivery

1996-2000

1997-99

1999

1999

1999

1999

1999-2000

1999-2000

2000

2001

2002

2003

2004-06

2009

Strategy, Policy, \& Review (SPR), in conjunction with Debt Relief International (DRI) and the Macroeconomic and Financial Management Institute of Eastern and Southern Africa (MEFMI). 
Debt Strategy National Workshop

SPR/AFR

Diagnosis of debt-data management

Fiscal Affairs Department (FAD)

Short-term visits:

Tax and customs administration $\quad 2001$

Public expenditure management 2003

Public expenditure management follow-up 2003

Tax administration workshop 2005

Fiscal ROSC mission 2006

\section{Statistics Department (STA)}

Short-term visits:

Government finance statistics 2000

Balance of payments statistics 2001

Money and banking statistics 2002

External sector statistics 2009

As part of the General Data Dissemination System (GDDS) Project:

Balance of payments statistics 2002

Balance of payments statistics 2003

Government finance statistics $\quad 2003$

National accounts statistics 2003

Balance of payments statistics 2004-05

National accounts statistics 2004-05

Consumer price index statistics 2004

Government finance statistics 2006

\section{Legal Department (LEG)}

Financial institution legislation $\quad 2004$

International Capital Markets Department (ICM)

Technical assistance on bond issuance 2004

Legal (LEG)/Monetary and Capital Markets (MCM)

Review of exchange arrangements and restrictions 2006/2007

XII. Resident Representative: No 
AnNex II-Angola: Joint IMF-World Bank Management ACtion Plan

Implementation Matrix

\begin{tabular}{|c|c|c|c|}
\hline Title & Products & $\begin{array}{c}\text { Provisional } \\
\text { Timing of } \\
\text { Missions }\end{array}$ & $\begin{array}{c}\text { Expected } \\
\text { Delivery Date }\end{array}$ \\
\hline
\end{tabular}

A. Mutual Information on Relevant Work Programs

\begin{tabular}{|c|c|c|}
\hline \multirow{8}{*}{$\begin{array}{l}\text { Bank work } \\
\text { program in } \\
\text { next } 12 \\
\text { months }\end{array}$} & $\begin{array}{l}\text { Implementing current Interim Strategy } \\
\text { Note and preparation of a new Full - } \\
\text { fledged Country Assistance Strategy. }\end{array}$ & $\begin{array}{l}\text { September } \\
2010\end{array}$ \\
\hline & $\begin{array}{l}\text { Small Holder Agriculture Development } \\
\text { Project - effectiveness }\end{array}$ & May 2010 \\
\hline & $\begin{array}{l}\text { Water Sector Institutional Development } \\
\text { Project - effectiveness }\end{array}$ & May 2010 \\
\hline & $\begin{array}{l}\text { Social Fund Project for Municipal } \\
\text { Development and Local Delivery of } \\
\text { Public Goods (FAS 4) - Effectiveness }\end{array}$ & June 2010 \\
\hline & Health Project - Approval & June 2010 \\
\hline & $\begin{array}{l}\text { Public Investment Management Analysis } \\
\text { and Prioritizing Public Investment Policy } \\
\text { Note }\end{array}$ & May 2010 \\
\hline & Education Country Status Report & December 2010 \\
\hline & Capacity Building Strategy & May 2010 \\
\hline \multirow{3}{*}{$\begin{array}{l}\text { IMF work } \\
\text { program in } \\
\text { next } 12 \\
\text { months }\end{array}$} & First review of the SBA & May 2010 \\
\hline & Second and third review of the SBA & October 2010 \\
\hline & Fourth review of the SBA & December 2010 \\
\hline
\end{tabular}

B. Request for Work Program Inputs

\begin{tabular}{|c|l|l|l|}
\hline $\begin{array}{c}\text { Fund request } \\
\text { to Bank }\end{array}$ & $\begin{array}{l}\text { TA on prioritizing capital spending } \\
\text { (including a criteria to determine which } \\
\text { projects to include in the government's } \\
\text { public investment program, including } \\
\text { cost-benefit analysis) }\end{array}$ & TBC \\
\hline $\begin{array}{c}\text { Bank request } \\
\text { to Fund }\end{array}$ & $\begin{array}{l}\text { Continuous dialogue on economic } \\
\text { forecast and macroeconomic modeling } \\
\text { issues for Angola }\end{array}$ & August 2009 \\
\hline
\end{tabular}




\section{Agreement on Joint Programs and Missions}

\begin{tabular}{|c|l|l|l|}
\hline $\begin{array}{c}\text { Joint products } \\
\text { in next } 12 \\
\text { months }\end{array}$ & FSAP & $\begin{array}{l}\text { Better monitoring of public enterprises } \\
\text { (including to reduce fiscal risks) }\end{array}$ & April 2010 \\
\cline { 2 - 4 } & $\begin{array}{l}\text { Exchange of information and mutual } \\
\text { consultations on macroeconomic } \\
\text { developments }\end{array}$ & Continuous \\
\hline
\end{tabular}




\section{ANNEX III-ANGOLA: STATISTICAL ISSUES}

1. Data provision has some shortcomings, but is broadly adequate for surveillance. There are major concerns about data quality and timeliness and efforts are underway to strengthen the statistical base, including through technical assistance from the Fund and the World Bank. The authorities are committed to using the GDDS to improve the statistical system. Angola has participated in the GDDS project for Lusophone African countries, and received technical assistance. Angola started participating in the GDDS in October 2003 and metadata were posted on the IMF's Dissemination Standards Bulletin Board. The metadata need to be updated.

2. The only regular statistical publication is the quarterly National Bank of Angola (BNA) statistical bulletin, which is often published with a considerable delay. It is complemented by the BNA website (www.bna.ao). Data postings on the government website (www.minfin.gv.ao), including revenues from the oil sector, have not been as timely as recommended in the GDDS. Government accounts are released when the annual budget is approved.

\section{National accounts and price statistics}

3. Among deficiencies in national accounts data are breaks in time series and intersectoral inconsistencies. Official GDP estimates are produced annually and generally only by sector, with no disaggregation by industry. Annual GDP at constant prices is estimated at previous-year prices using tentative deflators. There are no estimates of GDP by expenditure. Apart from oil production, sectoral data are calculated using indicators with weights based on incomplete surveys conducted in 2001 or earlier. A lack of statistical offices in the provinces significantly limits data coverage. The CPI is based on a basket of goods and services for which prices are collected in Luanda. The geographical coverage of price collection was extended to five more provinces and an unofficial quarterly index has been compiled commencing in 2005, but a September 2006 STA CPI Mission did not regard these data as sufficiently reliable for publication. The CPI weights were revised in January 2002 based on a household survey conducted in 2001. CPI data are produced monthly, normally with a lag of two weeks. There are no wholesale or producer price indices.

\section{Monetary and financial statistics}

4. Data for the depository corporation survey and the balance sheet of the central bank are timely but based on old report forms. There have been deficiencies in the reporting of foreign exchange reserves and concerns about the quality and timeliness of reports from some commercial banks. A March 2006 STA mission assisted the BNA in starting compilation of monthly monetary statistics using the new standardized report forms (SRFs). The mission made several recommendations for improving monetary statistics and finalizing the SRFs, including the classification of bank holdings of treasury bills and bonds and central bank bills, and the valuation of foreign currency-denominated accounts. Further priorities 
were to improve accounting procedures in state-owned banks and strengthen BNA's internal controls, particularly for external transactions. The implementation of the mission's recommendations was incomplete, although there was progress in preparing a new plan of accounts for the other depository corporations, which is expected to be implemented in 2009.

5. A May 2007 follow-up mission assisted the BNA in finalizing the SRFs for the central bank, but further work is needed to finalize the SRF for the other depository corporations. The mission also focused on the intersectoral consistency of the monetary and the government finance and balance of payments statistics, and provided on-the-job training. Once the link between the SRFs and the new accounting data of the other depository corporations is finalized, the SRFs will be used to derive an integrated monetary database to meet the needs of AFR, STA, and the BNA.

\section{Government finance statistics}

6. Although the Ministry of Finance (MoF) has had a new chart of accounts for some time, the chart is not yet fully operational. Since 2004, the government has included in its budget execution data Sonangol's quasi-fiscal expenditures and assessments of its liabilities for payments of oil revenue due to the government. However, the data are often late and not subject to effective scrutiny. Data for capital expenditures are largely estimated, the classification system allows little room for analytic insight, and coverage is incomplete. Data from the SIGFE management information system are still limited in coverage and reliability. Monthly government accounts rely to an unusually large extent on estimates based on the budget rather than on actual execution figures. The MoF does not report government finance data for publication in the GFS Yearbook or in International Financial Statistics.

7. Participation in the GDDS project aims to improve the quality and timeliness of fiscal data. A May 2006 technical assistance mission found that recommendations from a MayJune 2003 government finance statistics mission had only been partially implemented. The fiscal programming unit (established in the MoF with USAID support) will seek to systematize collection, analysis, and consistency checks for monthly and annual government accounts. The unit has substantial training needs.

\section{External sector statistics}

8. The balance of payments and international investment position are compiled following the recommendations of the fifth edition of the IMF's Balance of Payments Manual. These statistics are compiled and disseminated annually, with a lag of nine months after the reference period. A technical assistance mission on external sector statistics was conducted in October-November 2007. The mission identified some progress in developing data collection instruments, particularly the implementation of the International Transactions Reporting System (ITRS). The regulatory framework and technical aspects of the ITRS are sound, and data collected by the system can be used as the basis for compiling the quarterly BOP. The corporate surveys proved to be effective in such sectors as oil, diamond mining, and insurance and were not effective in other sectors mainly due to the lack of capacity to 
conduct follow-up or impose penalties for non-reporting. The National Customs Directorate improved the coverage of foreign trade operations included in the statistical database that resulted in a significant increase in the coverage and detail of the data in the balance of payments. Improvements were observed also in the reporting of public external debt transactions, although interest data are missing. The mission noted that the continued improvement of the statistics depends on: (1) an increase in the rate of response to the surveys, including the adoption of administrative measures to curb noncompliance with reporting requirements; (2) implementation of tools and mechanisms for the organization, analysis and validation of ITRS data; (3) compliance with commitments in the agreements signed with the National Statistics Institute, and the MoF for access to their databases; and (4) integration of more data sources. 


\section{Angola: Table of Common Indicators Required for Surveillance}

(As of April 26, 2010)

\begin{tabular}{|c|c|c|c|c|c|}
\hline & $\begin{array}{c}\text { Date of } \\
\text { Latest } \\
\text { Observation }\end{array}$ & $\begin{array}{l}\text { Date } \\
\text { Received }\end{array}$ & $\begin{array}{l}\text { Data } \\
\text { Frequency }\end{array}$ & $\begin{array}{l}\text { Reporting } \\
\text { Frequency }\end{array}$ & $\begin{array}{l}\text { Publication } \\
\text { Frequency }^{5}\end{array}$ \\
\hline Exchange rates & Apr. 2010 & Apr. 2010 & $\mathrm{D}$ & $\mathrm{D}$ & $\mathrm{D}$ \\
\hline $\begin{array}{l}\text { International reserve assets and } \\
\text { reserve liabilities of the monetary } \\
\text { authorities }^{1}\end{array}$ & Mar. 2010 & Apr. 2010 & W & $M$ & M \\
\hline Reserve/base money & Mar. 2010 & Apr. 2010 & W & $M$ & $M$ \\
\hline Broad money & Feb. 2010 & Mar. 2010 & M & M & M \\
\hline Central Bank balance sheet & Mar. 2010 & Apr. 2010 & W & $M$ & $\mathrm{M}$ \\
\hline $\begin{array}{l}\text { Consolidated balance sheet of the } \\
\text { banking system }\end{array}$ & Feb. 2010 & Mar. 2010 & M & M & M \\
\hline Interest rates & Feb. 2010 & Mar. 2010 & M & M & M \\
\hline Consumer Price Index & Mar. 2010 & Apr. 2010 & M & M & $M$ \\
\hline $\begin{array}{l}\text { Revenue, expenditure, balance and } \\
\text { composition of financing }^{2}-\text { General } \\
\text { Government }^{3}\end{array}$ & Dec. 2009 & Feb. 2010 & $Q$ & $\mathrm{Q}$ & $Q$ \\
\hline $\begin{array}{l}\text { Revenue, expenditure, balance and } \\
\text { composition of financing }{ }^{2}-\text { Central } \\
\text { Government }\end{array}$ & Dec. 2009 & Feb. 2010 & Q & Q & Q \\
\hline $\begin{array}{l}\text { Central Government and Central } \\
\text { Government-guaranteed } \text { debt }^{4}\end{array}$ & Dec. 2009 & Feb. 2010 & Q & $Q$ & Q \\
\hline External current account balance & 2008 & Apr. 2009 & A & $A$ & $A$ \\
\hline $\begin{array}{l}\text { Exports and imports of goods and } \\
\text { services }\end{array}$ & 2008 & Apr. 2009 & $A$ & $A$ & $A$ \\
\hline GDP/GNP & 2008 & Apr. 2009 & A & A & A \\
\hline Gross external debt & Dec. 2009 & Feb. 2010 & M & Q & $M$ \\
\hline International Investment Position ${ }^{6}$ & 2008 & Feb. 2009 & $A$ & I & $A$ \\
\hline \multicolumn{6}{|c|}{${ }^{1}$ Includes reserve assets pledged or otherwise encumbered as well as net derivative positions. } \\
\hline \multicolumn{6}{|c|}{$\begin{array}{l}{ }^{3} \text { The general government consists of the central government (budgetary funds, extra budgetary funds, and social } \\
\text { security funds) and state and local governments. }\end{array}$} \\
\hline \multicolumn{6}{|c|}{${ }^{4}$ Including currency and maturity composition. } \\
\hline${ }^{5}$ Daily (D), weekly (W), monthly (M), qu & rterly (Q), anni & A), irregu & not availa & VA). & \\
\hline
\end{tabular}




\section{Statement by the Staff Representative \\ May 10, 2010}

This statement is intended to update Executive Directors on program-related developments in Angola since the issuance of the staff report for the First Review Under the Stand-By Arrangement and Request for a Modification of Performance Criteria. The new information does not alter the thrust of the staff appraisal.

\section{Prior Actions:}

There are three prior actions, listed in the staff report, page 42 .

- $\quad$ Audited financial statements for Sonangol (the state-owned oil company), which include its quasi-fiscal operations, for the years 2007 and 2008 were published on Friday, April 30, 2010 on Sonangol's website.

- $\quad$ The audited financial statements of the National Bank of Angola (BNA) for 2008 were published on Wednesday, April 28, 2010 on the BNA's external website: these are accompanied by the external auditor's signed audit opinion.

- Indications are that the audit of the BNA's financial statements for 2009 is substantially completed: staff is to confirm the precise status of the audit and the audit results in a dialogue with the external auditors on Friday, May 7.

\section{Program Performance:}

Preliminary data on the evolution of the BNA's balance sheet as of end-March indicate that the foreign reserve position continues to improve gradually, with net international reserves now on the order of USD 11 billion. As final data on program-related adjusters are not yet available, the staff cannot confirm that the end-March program target has been met, but all indications point to that conclusion; other elements of the monetary program also appear to be on track.

There has been some depreciation of the kwanza in recent weeks, bringing the cumulative depreciation to about 20 percent since October 2009. The end-March inflation rate was 13.8 percent on a twelve-month basis, essentially unchanged from the previous month and in line with staff expectations. 
Press Release No. 10/190

FOR IMMEDIATE RELEASE

May 10, 2010
International Monetary Fund

Washington, D.C. 20431 USA

\section{IMF Executive Board Completes First Review Under Stand-by Arrangement with Angola and Approves US\$171.5 Million Disbursement}

The Executive Board of the International Monetary Fund (IMF) today approved the first review of Angola's performance under an economic program supported by the Stand-by Arrangement (SBA). The approval enables the disbursement of SDR 114.52 million (about US\$171.5 million), bringing total disbursements under the arrangement to SDR 343.56 million (US\$514.5 million)

The Executive Board also granted waivers of non-observance for the continuous performance criterion on the non-accumulation of new external payment arrears and for the end-March 2010 quantitative performance criterion on the non-accumulation of new domestic payments arrears.

The 27-month SBA for SDR 858.9 million (about US\$1.3 billion) with Angola was approved on November 23, 2009 (Press Release No. 09/425) to help the country cope with the effects of the global economic crisis.

Following the Executive Board's discussion on Angola, Mr. Murilo Portugal, Deputy Managing Director and Acting Chair, stated:

"The authorities are to be commended for their good start in implementing a comprehensive reform program to address Angola's macroeconomic imbalances. The reforms are beginning to bear fruit, and the authorities are firmly committed to address the remaining challenges. The renewal of the foreign exchange auctions has facilitated an orderly and significant exchange rate adjustment, and further improvements in the workings of the foreign exchange auction system are planned. The elimination of the remaining administrative controls is a priority, once supportive reforms to improve liquidity management are in place.

"The increase of the program's external borrowing ceiling can be undertaken in light of Angola's large infrastructure needs and low debt burden, but it will be essential that the associated projects are soundly appraised and well implemented, and that the debt created is 
effectively managed. The authorities' commitments to strengthen public debt management and establish a project appraisal framework to ensure the efficient use of public resources are welcome.

"Fiscal policy will continue to be sufficiently tight to support the authorities' key goal of strengthening the external position and ensuring fiscal sustainability. The authorities' intention to lay out a concrete plan in the coming weeks to clear the stock of domestic arrears is welcome.

"The measures being taken by the National Bank of Angola (BNA) to publish their audited financial statements and to strengthen internal controls and the internal audit function are important steps of the BNA's own modernization strategy. The authorities' implementation of their reform program merits continued support from the Fund. The existing and proposed policy measures give confidence that program objectives and targets can be realized," Mr. Portugal added. 


\section{Statement by Samuel Itam, Executive Director for Angola \\ May 10, 2010}

\section{Introduction}

1. On behalf of my Angolan authorities, I want to thank management for the constructive engagement and support, and appreciate staff's collaboration and policy dialogue that is based on a shared understanding of and respect for the specific situation of the country. My authorities remain confident that the reforms and measures implemented during the period of the Stand-By Arrangement (SBA) will generate positive impacts on the fiscal and external accounts, help the country in facing the current crisis from a position of strength, and create the basis for medium- to long-term sustained economic growth. Ultimately, the adjustment program would improve the living conditions of the Angolan people.

2. The program is broadly on track, with all but two end-December 2009 performance criteria being met. Given the corrective policy measures undertaken and being implemented, the authorities request the granting of waivers and the completion of the first review under the SBA. Notwithstanding the noted progress and the authorities' perseverance in undertaking prudent macroeconomic policies and embarking on structural reforms, challenges remain. In this regard, Fund's support and engagement will be helpful to strengthen market confidence and focus the reform agenda towards restoring macroeconomic balances, and improving public finance management and fiscal transparency.

\section{Outlook and policies}

3. After a slowdown of real GDP growth in 2009, due mainly to the decline in oil output, there is an expectation of a strong rebound in 2010, as the price and output of oil recover. During the period of the SBA, a steady increase in oil production, a rise in the agricultural output due to coming on stream of projects to increase cereal and cash crops, and production of biofuel will be important drivers of growth. On the demand side, the primary drivers of growth will be government expenditure and private consumption.

4. Going forward, the key policy challenge for the authorities is to maintain a growth process that balances capital-intensive and import-dependent activities with those that have substantial linkages with the other sectors of the economy to help the development of a dynamic private sector. In addition, the youth structure of the Angolan population augurs well for the maintenance of relatively high growth in the coming years. Therefore, economic diversification is vital for the long-term growth, and, accordingly, the need for structural change to cope with the future waning of oil production. 
5. The authorities are aware of the medium-term challenges facing the economy and will continue to take appropriate measures to mitigate them. In this context, they are persevering with the current reforms and are initiating additional key reforms, namely: (i) enhancing public finance management; (ii) strengthening debt management capacity; (iii) adopting structural measures to improve the growth potential of the non-oil sector; and, (iv) strengthening the legal and institutional framework for effective public administration and the inter-generational use of natural resource endowments of the country.

\section{Fiscal policy}

6. The authorities are working towards the implementation of the poverty reduction program as well as the second wave of infrastructure rehabilitation and construction without jeopardizing macroeconomic stability. 2009 was characterized by a tight fiscal stance. However, the government accumulated domestic arrears, mostly due to internal financing operations constraints. The fiscal position is projected to improve in 2010, as oil revenue recovers on account of both rising output and higher international prices. To avoid vulnerabilities and slippages, budget execution will be assessed frequently. In this regard, the authorities will continue with a wide range of fiscal reforms, as clearly expressed in the Letter of Intent (prior actions and structural benchmarks), to limit fiscal risks and improve transparency and public financial management.

7. Recently the Cabinet discussed two important draft legislations on the general framework for the budget and on public sector procurement for public works and acquisition of goods and services. These legislations will set the ground for best practices. Regarding domestic arrears, the authorities estimate that the zero level performance criterion for endMarch 2010 was exceeded. The Cabinet has approved a framework to deal with this situation, with creditors divided into three groups: small, medium and large. For the first group, the government will pay all outstanding debt at once; for the second group, the government will pay 50 percent as soon as possible and the remainder later; while for the third group, 30 percent will be paid as soon as possible and the remainder will be a rescheduled. These measures will be implemented with a view to avoid disturbing the financial sector, as well as guaranteeing the appropriate management of both fiscal and monetary policies.

\section{Monetary and exchange rate policies}

8. Inflation averaged 13.7 percent (14 percent end-December) in 2009, driven by food prices in the second half of the year and supply bottlenecks in the country's import system. The depreciation of the Kwanza since the second half of 2009 has revived inflationary pressures. However, the proposed tight fiscal and monetary policies in 2010 will help keep prices under control. The Banco Nacional de Angola (BNA) will continue its efforts to use a mix of measures to address the money supply through appropriate reserve requirements and use of Treasury securities in open market operations. 


\section{Financial sector}

9. The authorities believe that maintaining confidence in the financial system is a priority. At the same time, the extensive dollarization due to lack of monetary instruments and the shallow markets exert additional challenges. In this regard, the authorities are determined to put in place a comprehensive strategy to strengthen the financial sector, in particular on prudential regulations, loan classification, provisioning standards, and supervision and oversight of the financial sector. The authorities also remain vigilant about risks, in particular, those that can affect banks' credit quality due to foreign currency lending and potential mismatches in case of volatility of the exchange rate. They appreciate the importance of effective coordination of monetary and fiscal policies and the prudent management of foreign reserves in the context of protecting the stability of the financial sector in the long run.

10. The structural benchmarks included in the program for the rest of 2010 are important to support the authorities' efforts to preserve and strengthen the financial sector and improve supervision of and compliance by the banking sector in line with international best practices. The authorities look forward to benefit from the Fund's expertise and the different TA missions, and in particular from the Fund's cross-country experience to help strengthen the financial sector, as well as the central bank's governance and transparency.

\section{Conclusion}

11. Angola faces particular challenges going forward. The economy has a structural dependence on oil for its exports earnings and for government revenues. On the other side, there are immense opportunities arising from: (i) ongoing infrastructure investments which can help boost long-term growth; and (ii) potential investments in agriculture given its soil and weather. In this context, the authorities value the close engagement, dialogue, and frequent exchange of views with the Fund to strengthen policy design and implementation, and in monitoring the economy. The current SBA will further enhance this dialogue. 